OPEN ACCESS

Edited by:

Reem Al-Daccak,

Institut National de la Santé et de la

Recherche Médicale (INSERM),

France

Reviewed by:

Paolo Fiorina,

University of Milan, Italy

Oleh Andrukhov,

University Dental Clinic Vienna, Austria

${ }^{*}$ Correspondence:

Mohamed A. Ghoneim

ghoneimma@yahoo.com

Specialty section:

This article was submitted to Alloimmunity and Transplantation,

a section of the journal

Frontiers in Immunology

Received: 03 April 2021 Accepted: 09 June 2021

Published: 23 June 2021

Citation:

Refaie AF, Elbassiouny BL, Kloc M, Sabek OM, Khater SM, Ismail AM,

Mohamed $\mathrm{RH}$ and Ghoneim MA (2021) From Mesenchymal Stromal/ Stem Cells to Insulin-Producing Cells: Immunological Considerations.

Front. Immunol. 12:690623. doi: 10.3389/fimmu.2021.690623

\section{From Mesenchymal Stromal/Stem Cells to Insulin-Producing Cells: Immunological Considerations}

\author{
Ayman F. Refaie ${ }^{1}$, Batoul L. Elbassiouny ${ }^{2}$, Malgorzata Kloc ${ }^{3,4,5}$, Omaima M. Sabek ${ }^{4,6}$, \\ Sherry M. Khater ${ }^{7}$, Amani M. Ismail ${ }^{8}$, Rania H. Mohamed ${ }^{9}$ and Mohamed A. Ghoneim ${ }^{10 *}$ \\ ${ }_{1}^{1}$ Nephrology Department, Urology and Nephrology Center, Mansoura, Egypt, ${ }^{2}$ Biotechnology Department, Urology and \\ Nephrology Center, Mansoura, Egypt, ${ }^{3}$ Department of Immunobiology, The Houston Methodist Research Institute, Houston, \\ TX, United States, ${ }^{4}$ Department of Surgery, The Houston Methodist Hospital, Houston, TX, United States, ${ }^{5}$ Department of \\ Genetics, The University of Texas, M.D. Anderson Cancer Center, Houston, TX, United States, ${ }^{6}$ Department of Cell and \\ Microbiology Biology, Weill Cornell Medical Biology, New York, NY, United States, 7 Pathology Department, Urology and \\ Nephrology Center, Mansoura, Egypt, 8 Immunology Department, Urology and Nephrology Center, Mansoura, Egypt, \\ ${ }^{9}$ Biochemistry Department, Faculty of Science, Ain Shams University, Cairo, Egypt, 10 Urology Department, Urology and \\ Nephrology Center, Mansoura, Egypt
}

Mesenchymal stem cell (MSC)-based therapy for type 1 diabetes mellitus (T1DM) has been the subject matter of many studies over the past few decades. The wide availability, negligible teratogenic risks and differentiation potential of MSCs promise a therapeutic alternative to traditional exogenous insulin injections or pancreatic transplantation. However, conflicting arguments have been reported regarding the immunological profile of MSCs. While some studies support their immune-privileged, immunomodulatory status and successful use in the treatment of several immune-mediated diseases, others maintain that allogeneic MSCs trigger immune responses, especially following differentiation or in vivo transplantation. In this review, the intricate mechanisms by which MSCs exert their immunomodulatory functions and the influencing variables are critically addressed. Furthermore, proposed avenues to enhance these effects, including cytokine pretreatment, coadministration of mTOR inhibitors, the use of Tregs and gene manipulation, are presented. As an alternative, the selection of high-benefit, low-risk donors based on HLA matching, PD- $L_{1}$ expression and the absence of donor-specific antibodies (DSAs) are also discussed. Finally, the necessity for the transplantation of human MSC (hMSC)-derived insulin-producing cells (IPCS) into humanized mice is highlighted since this strategy may provide further insights into future clinical applications.

Keywords: mesenchymal stem cells, insulin-producing cells, immunomodulation, immunogenicity, diabetes mellitus

\section{INTRODUCTION}

Type 1 diabetes mellitus (T1DM) accounts for approximately 5\% of all diabetes cases and occurs as the result of the destruction of pancreatic islets through an autoimmune-mediated process. Patients typically depend on exogenous insulin injections throughout their lives. Glycaemic control can otherwise be achieved by $\beta$-cell replacement via the transplantation 
of the entire pancreas or its islets. Despite the increasing success of these methods, their application is limited by organ availability and the need for lifelong immunosuppression.

Recent progress in the field of regenerative medicine provides an alternative approach whereby surrogate $\beta$-cells can be generated from various stem cell sources. To this end, mesenchymal stromal/stem cells (MSCs) provide several distinct advantages, as they are widely obtainable from several tissues and have been reported to be safe and well tolerated with negligible teratogenic risk. MSCs can be selected on the basis of certain standards proposed by the Mesenchymal and Tissue Stem Cell Committee (1). Evidence was also provided that MSCs can be differentiated in vitro into insulin-producing cells (IPCs). This can be achieved by gene transfection with relevant endocrine genes (2), gene editing (3), or directed differentiation, whereby MSCs are cultured in a glucose-rich medium with a variety of activation and growth factors (4-7). In experimental animals, the efficiency of human MSC (hMSC)-derived IPCs in controlling chemically-induced diabetes was comparable to, if not better than, that of pluripotent stem cell-derived $\beta$-cells (8). An intriguing feature of MSCs is their ability to evade immune recognition. This immune-privileged status is attributed to their lack of expression of Human Leukocyte Antigen (HLA) class II, as well as the costimulatory molecules CD40, CD80 and CD86. Since MSCs can be harvested, expanded and stored for use, allogeneic MSCs are more practical for clinical applications than other cell types. However, many questions remain: will allogeneic hMSC-derived IPCs retain their immunomodulatory properties or become immunogenic after differentiation? And will they be susceptible to the detrimental effects of the in vivo microenvironment that destroyed native $\beta$-cells in type 1 diabetic patients after transplantation? This review will critically address these issues.

\section{ALLOGENEIC MSCs ARE IMMUNOMODULATORY}

The immunomodulatory properties of MSCs were recognized approximately 2 decades ago. Bartholomew and associates reported one of the earliest in vitro and in vivo studies (9). When added to mitogen-stimulated lymphocytes, MSCs inhibited lymphocyte proliferation by approximately $50 \%$. In vivo, the administration of MSCs to mismatched recipient baboons resulted in prolonged allograft survival of a thirdparty skin graft. These observations were further supported by several follow-up studies (10-14). Based on these findings, the immunomodulatory functions of hMSCs were exploited for the treatment of refractory immune-mediated diseases. Of these, the most frequently studied included graft-versus-host disease (15), aplastic anaemia (16), multiple sclerosis (17), rheumatoid arthritis (18), Crohn's disease (19) and systemic lupus erythematosus (20).

\section{ALLOGENIC MSCS ARE IMMUNOGENIC}

In contrast, a number of studies questioned the immunomodulatory capacity of allogenic MSCs and advocated that these cells are instead immunogenic $(21,22)$. Berglund and colleagues emphasized the importance of proper controls for matched or mismatched major histocompatibility complex (MHC) when investigating the immunogenicity of allogeneic MSCs (23). The researchers reported that MHC-mismatched MSCs evoked cell-mediated and humoral immune responses in vivo. In another study, Poncelet et al. showed that allogeneic porcine MSCs, which exhibited no immunogenicity in vitro, elicited an immune response following intracardiac injection (24). Furthermore, some reports argued that MSCs may acquire immunogenicity after differentiation. Lohan and associates demonstrated that, following MSC differentiation, the expression of immunological markers was induced and the secretion of immunomodulatory molecules, specifically prostaglandin E2 (PGE2), was suppressed (25). Similarly, Ryan et al. showed that allogeneic MSC-derived chondrocytes developed enhanced susceptibility to lysis by $\mathrm{T}$ cells following transplantation (26).

\section{THE SPECIAL CASE OF STEM CELL-DERIVED IPCs}

The immunogenicity of human umbilical cord-derived MSCs (hUC-MSCs) before and after directed differentiation to IPCs was investigated by Yang et al., both in vitro and in vivo. The authors reported that hUC-MSC-derived IPCs were hypoimmunogenic in vitro but evoked an allogeneic response after their transplantation in immune-competent mice (27). In a similar experiment, Hassanin et al. differentiated MSCs isolated from human umbilical cord Wharton's jelly into IPCs (28). The researchers noted that the differentiated cells exhibited weak immunogenicity in vitro. However, following transplantation into chemically-induced diabetic rats via the portal vein, an immune response was induced. It is surprising to assume that the immunomodulatory capacity of MSCs could be effective across such a wide xenogeneic spectrum. In another study by van der Torren et al., human embryonic stem cell (hESC)-derived pancreatic progenitors were encapsulated and transplanted into NOD/SCID mice for further differentiation (29). Following maturation (20-25 weeks), the engrafted endocrine cells were explanted for in vitro immunogenicity testing. They observed that the differentiated cells became immunogenic compared to their hypoimmunogenic progenitors. We suggest that such an experiment would have been more informative if humanized mice had been utilized. On another note, a review by Sordi and colleagues reported that autologous induced pluripotent stem cells (iPSCs) and their differentiated IPCs were immunogenic (30). Such an observation was attributed to epigenetic modifications resulting from reprogramming and differentiation. However, Wood et al. highlighted several reports demonstrating reduced iPSC immunogenicity following 
differentiation (31). The authors also noted that the type of differentiated cells could influence the potential immunogenicity. According to Melton, a vigorous autoimmune response is expected following the transplantation of autologous iPSCderived islets (32). Recently, in an in vitro investigation, Mohammadi and associates explored the immunogenicity of murine bone marrow-derived MSCs (BM-MSCs) after their differentiation to IPCs (33). They noted that differentiated MSCs acquired immunogenic properties. Such in vitro experiments, however, overlook the influence of the in vivo microenvironment.

Overall, the immunogenicity of pluripotent stem cell-derived IPCs has been confirmed. Their utilization in the clinical setting should, therefore, be within an immunoisolation device. On the other hand, the reported results of the potential immunogenicity of naïve allogeneic MSCs or their derived IPCs were conflicting. This discrepancy highlights the need to characterize the intricate mechanisms by which MSCs exert their immunomodulatory properties and identify the variables that may influence these functions.

The current understanding is that islet cells are both the driver for and the target of the autoimmune T1DM. It is widely believed that genetic predisposition underlies individual susceptibility to the disease (34). However, monozygotic twins do not exhibit identical susceptibility to T1DM, which indicates the contribution of additional factors, such as metabolic stress (35), viral infection (34) and changes in the intestinal microbiota (36). As a result of impaired thymic education, islet-specific autoreactive lymphocytes migrate from the pancreas-draining lymph nodes to the islets, where they mediate $\beta$-cell destruction $(35,37)$. The detection of autoantibodies against islet proteins [insulin (IAA), glutamic acid decarboxylase 65 (GAD65), zinc transporter 8 (ZnT8) and insulinoma-associated antigen-2 (IA-2)] is believed to be the best predictor of the course and clinical manifestation of T1DM (38). However, the role of autoantibodies in disease pathogenesis is not yet well understood (39). In an immunohistological investigation in our laboratory, we observed that while undifferentiated MSCs did not express GAD65, differentiated MSCs did (Figure 1). GAD65 serves to convert glutamic acid into gamma aminobutyric acid (GABA) (38), which is thought to take part in $\beta$-cell proliferation and regeneration and glucose homeostasis (40). These findings suggest that MSC-derived IPCs exhibit some biological similarities to naïve islets and might be affected by the same events that result in T1DM. This conclusion raises a key question of whether the immunomodulatory functions of MSCs and their derived IPCs can overcome allogeneic responses and modulate the autoimmune pathways implicated in T1DM.

\section{MSCs AND IMMUNE SYSTEM COMPONENTS}

Several reports have demonstrated that MSCs can modulate the activation and function of various immune cells belonging to both the innate and adaptive components of the immune system.
It has also been shown that MSCs are capable of exerting their immunosuppressive effects especially in an inflammatory environment where they are activated by proinflammatory cytokines. Of these, IFN- $\gamma$ is the most essential, acting synergistically with TNF- $\alpha$. IL-1 and IL-17 can also boost MSC-mediated immunomodulation. It is worthy to note that different cytokines activate distinct signaling pathways and might differently regulate the mechanisms involved in the immunomodulatory properties of MSCs $(41,42)$.

\section{MSCs, T Lymphocytes and Their Effector Cells}

In vitro, MSCs can suppress the proliferation of T-cells induced by allo-antigens or mitogens (43-46). This is primarily the result of cell division arrest at the $G_{0} / G_{1}$ phase of the cell cycle (47) and is thought to be mediated by cell-to-cell interactions along with the release of cytokines and soluble factors (48). MSCs are also capable of inducing apoptosis in activated $\mathrm{T}$ cells; a process associated with the conversion of tryptophan into kynurenine (49) or through the FasL-mediated pathway (50). In addition, MSCs exert suppressive actions on T cell differentiation towards the proinflammatory T-helper (Th) subsets Th1 and Th17 (51). In their experimental study, Luz-Crawford et al. reported that, in the presence of MSCs, significant reductions in the numbers of IFN- $\gamma$-producing $\mathrm{CD}^{+}$Th1 cells and IL-17-producing Th17 cells were observed (52). In addition, the researchers observed an increase in the proportion of FOXP3-expressing regulatory $\mathrm{T}$ cells (Tregs). Ghannam et al. reported that, in an inflammatory environment, MSCs triggered the regulatory properties of CD $4^{+}$ Th17 cells. They maintained that this effect is achieved by downregulating the Th17 cell-specific transcription factor retinoic acid receptor-related orphan receptor gamma $t$ (ROR $\gamma \mathrm{t}$ ) and upregulating FOXP3 (53).

On another note, $\mathrm{CD}^{+}$cytotoxic $\mathrm{T}$ lymphocytes (CTLs) are activated upon interacting with peptides expressed on $\mathrm{MHC}$ class-I (54). Despite their expression of MHC class-I, MSCs do not activate CTLs (55). Instead, MSCs have been shown to suppress the differentiation of CTL precursors into effector CTLs. The early addition of MSCs to a mixed lymphocyte culture (MLC) significantly inhibited the lytic activity of CTLs against target cells. However, lysis was not affected when MSCs were added on or after day 3 (56), revealing the inability of MSCs to exert their inhibitory effects once the cytotoxic phase of CTLs had been reached.

\section{MSCs and Regulatory T Lymphocytes (Tregs)}

Sakaguchi et al. isolated a unique population of $\mathrm{CD} 4^{+} \mathrm{CD} 25^{+} \mathrm{T}$ cells that exhibited immunosuppressive properties. Later, this subpopulation was given the name Tregs (57). Based on their developmental origin, Tregs are classified into two major categories: those that develop naturally in the thymus (nTregs) and those that are induced peripherally during activation (iTregs). In contrast to nTregs, which express demethylated FOXP3, iTregs are inducible, and their FOXP3 is fully methylated (58). Several reports have demonstrated that MSCs 

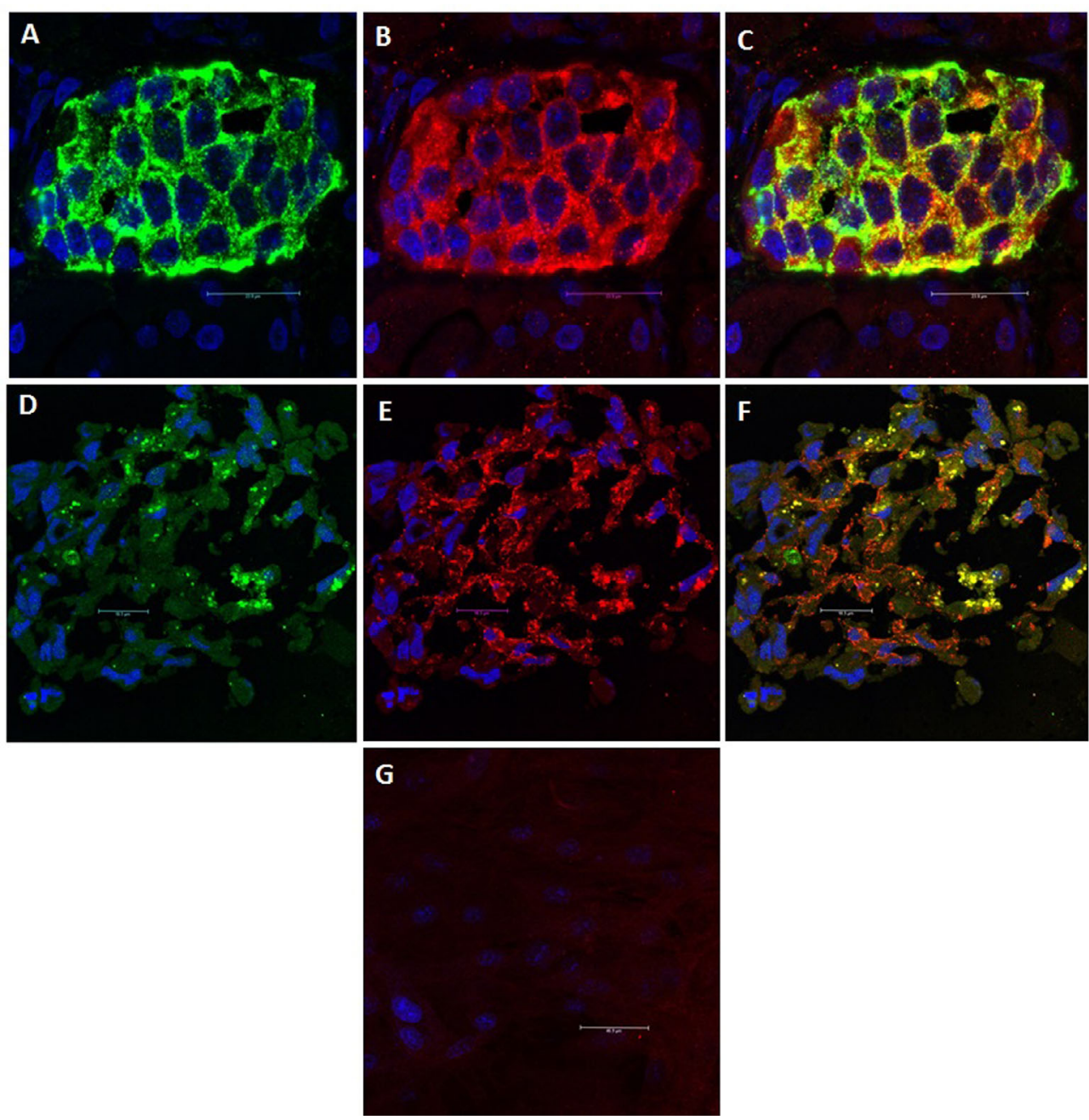

FIGURE 1 | GAD65 Expression: GAD65 converts glutamic acid into GABA, which takes part in $\beta$-cell proliferation and regeneration and glucose homeostasis. (A) Human islets: Positive staining for insulin (Green). (B) Human islets: Positive staining for GAD65 (Red). (C) Human islets: Electronic merging revealed the presence of GAD65 within the majority of insulin-producing cells (Yellow). (D) MSC-derived IPCs: Positive staining for insulin (Green). (E) MSC-derived IPCs: Positive staining for GAD65 (Red). (F) MSC-derived IPCs: Electronic merging revealed the presence of GAD65 within the majority of insulin-producing cell (Yellow). (G) Negative staining for GAD65 in undifferentiated MSCs.

are able to trigger Treg proliferation both in vitro and in vivo (59-61). Evidence has shown that this proliferation is induced and not the result of the expansion of nTregs $(53,62)$. To date, four mechanisms have been proposed for this process: cell-to-cell contact-dependent, soluble factor-dependent, antigenpresenting cell (APC)-dependent and exosome-dependent. In vitro studies by English and associates demonstrated that MSCs promoted Treg activation via a sequential process: cell-to-cell contact with $\mathrm{CD}^{+} \mathrm{T}$ cells which was followed by the release of PGE2 and transforming growth factor-beta (TGF- $\beta$ ) (63). Fallarino and colleagues claimed that the induction of a regulatory phenotype in naïve $\mathrm{T}$ cells was the result of tryptophan starvation and its catabolites (64). In addition, MSCs were shown to drive APCs towards a regulatory phenotype that promoted Treg activation through interleukin10 (IL-10) secretion $(65,66)$. On the same note, Zhang et al. reported delayed rejection of allogeneic skin grafts in mice with polarization of $\mathrm{CD} 4^{+}$cells towards $\mathrm{CD} 4^{+} \mathrm{CD} 25^{+} \mathrm{FOXP}^{+}$Tregs as a function of MSC-derived exosomes (67). Infusion of those exosomes into a humanized mouse model of graft-versus-host reaction resulted in reduced mortality and increased numbers of Tregs (68). Although the potential of MSC-derived exosomes is promising, their role in Treg induction, in comparison to other mechanisms, has yet to be validated.

\section{MSCs and B Lymphocytes}

In their in vivo experiments, Corcione et al. demonstrated that human BM-MSCs inhibited the proliferation of stimulated B cells and suppressed their differentiation to antibody-producing cells (plasmablasts) in vivo (69). The expression of the chemokine CXCR4 was preferentially downregulated, resulting in the retardation of $B$ cell chemotaxis. Transwell experiments further 
confirmed that the inhibitory effect of MSCs on activated B lymphocytes was mediated by the release of soluble factors. In another study, Franquesa et al. reported that the activation of human adipose tissue-derived MSCs (hAT-MSCs) by inflammatory cytokines induced the expression of indoleamine2,3-dioxygenase (IDO) and programmed death ligand 1 (PD- $\left.\mathrm{L}_{1}\right)$. The activated cells were then able to inhibit the proliferation of $\mathrm{B}$ cells in vitro (70). They also observed that hAT-MSCs had a direct effect, independent of T cells, on stimulated B cells, inhibiting their differentiation into plasmablasts and triggering the formation of regulatory B cells (Bregs). Luk and associates stressed the fact that the immunological conditions dictate the influence of MSCs on B cell functions (71). Under resting conditions, hAT-MSCs stimulated IL-10-producing Bregs. Whereas, in an inflammatory microenvironment, they inhibited B cell proliferation.

\section{MSCs and Natural Killer (NK) Cells}

Several studies have proven that MSCs suppress NK cell proliferation and cytokine production (72). In such cases, the ratio of MSCs to NK cells is critical; the suppressive action requires a high $\mathrm{MSC}$-to-NK cell ratio (73). It was also confirmed that MSCs induce CD73 upregulation in NK cells. As a result, adenosine monophosphate (AMP) is converted into adenosine, which is an anti-inflammatory molecule (74). Conversely, at low ratios, MSCs were shown to support NK cell proliferation (75). In a more recent study by $\mathrm{Hu}$ and associates, NK cells were cocultured with MSCs at a ratio of 10:1 (76). The authors noted that MSCs did not alter NK proliferation but reduced their IFN- $\gamma$ production and lytic functions. They maintained that these effects were mediated by IDO and PGE2.

\section{MSCs and Dendritic Cells (DCs)}

Monocytes and $\mathrm{CD}_{3} 4^{+}$hematopoietic progenitor cells (HPCs) can differentiate into macrophages or DCs, the most potent APCs that can activate $\mathrm{T}$ cells and initiate immune responses. It was reported that MSCs prevent the differentiation into mature DCs from either source (77). Transwell experiments by Nauta et al. indicated that the underlying mechanisms involved the release of soluble factors, mainly IL-6 and IL-10 (78). Similarly, the coculture of mature DCs with MSCs resulted in reduced expression of CD80, CD83 and CD86, along with the downregulation of IL-12, indicating that DCs were driven into an immature state (45). Additionally, Li et al. showed that direct coculture of MSCs with adult $\mathrm{CD}_{3}{ }^{+}$HPCs induced the generation of alloantigen-specific Tregs (79). The authors suggest that this action involved direct contact between MSCs and HPCs and was mediated by activation of the Notch signalling pathway. These MSC-primed DCs can, therefore, be considered regulatory since they express high levels of IL-10, inhibit the proliferation of alloreactive $\mathrm{T}$ cells and induce the generation of allogen-specific Tregs.

\section{MSCs and Macrophages}

Macrophages have both proinflammatory and anti-inflammatory roles and can thus take part in tissue inflammation and damage on one hand, and repair and healing on the other. Several in vitro studies have demonstrated that coculturing macrophages with MSCs resulted in macrophage polarization towards an immunomodulatory M2 phenotype, that secreted high levels of IL-10 (80-82). To exert their therapeutic functions, MSCs can be primed with proinflammatory TNF- $\alpha$ and anti-inflammatory IL10 cytokines produced by M1 and M2 macrophages, respectively (83). Evidence was provided that induced MSCs secrete regulatory molecules such as PGE2, which promote M2 macrophages and suppress M1 macrophages. Li et al. showed that the interaction between MSCs and M1 macrophages is not only paracrine but also contact-dependent via the interaction between CD200 expressed by MSCs and its receptor CD200R on the M1 macrophage surface (84). In the context of the subject matter of this review, it is of interest that macrophages are the main immune cell component of murine and human islets (85). Dalmas and associates reported that islet-associated macrophages are in close proximity to $\beta$-cells and regulate insulin secretion through the production of retinoic acid (86). According to Weitz et al., macrophages reside in perivascular regions and produce anti-inflammatory IL-10, which is notably reduced in obese/diabetic individuals (87). Collectively, these findings can provide further insight into MSC-based therapy for T1DM.

\section{MSCs and Neutrophils}

A number of studies have confirmed the preservative role of MSCs on neutrophil viability and function (88-90). Such protective effect is mediated by MSC release of IL-6. In contrast to their suppressive action on other immune cells, MSC-mediated protection of neutrophils was proven to be vital for maintaining neutrophil phagocytic and bactericidal functions.

\section{MECHANISMS OF MSC-MEDIATED IMMUNOMODULATION}

The mechanisms underlying the immunomodulatory properties of MSCs are interdependent and involve soluble factor secretion and cell-to-cell contact (Figure 2).

\section{Soluble Factors}

\section{Transforming Growth Factor- $\beta$ (TGF- $\beta$ )}

As early as 1999, TGF- $\beta$ was recognized as a cytokine that was secreted by MSCs and plays a role in the regulation of the immune response (91). Tomic et al. reported that MSCs isolated from dental pulp produced TGF- $\beta$, which suppressed the proliferation of peripheral blood mononuclear cells (PBMCs). This action was blocked by the addition of anti-TGF- $\beta$ antibodies (92). In a study by Nasef et al., the suppressive effect of MSC-produced TGF- $\beta$ on $\mathrm{T}$ cell proliferation was shown to be largely dependent on cell-to-cell contact (93). It was also noted that TGF- $\beta$ could modulate the differentiation of T-helper subsets by promoting Th2 and inhibiting Th1 and Th17 responses (94). Moreover, English and colleagues demonstrated that BM-MSCs induced FOXP3 ${ }^{+}$Tregs via TGF- $\beta$ in vitro (63). This finding was confirmed by Wang et al., who demonstrated 


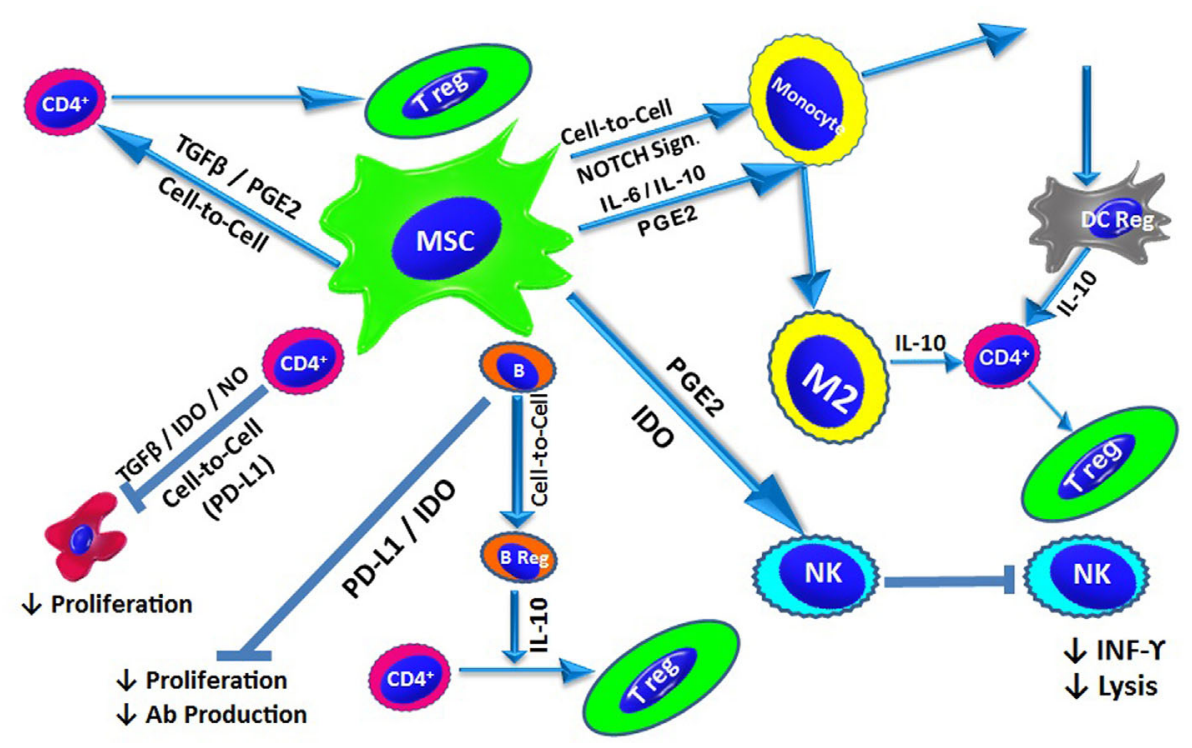

FIGURE 2 | MSC-Mediated Immunomodulation: Under inflammatory conditions, MSCs exert their immunomodulatory effect via cell-to-cell contact and/or the release of soluble factors. In addition to contact-dependent inhibition, MSCs suppress T cell proliferation by secreting IDO, NO and TGF- $\beta$. MSCs also modulate naïve T cells to generate Tregs through cell-to-cell contact, as well as via TGF- $\beta$ and PGE2. B cell proliferation and antibody production is inhibited by IDO and PD- $L_{1}$. Through direct interactions, MSCs also promote the generation of IL-10-producing Bregs. MSCs affect the innate immune system and suppress NK cell proliferation and cytokine secretion, a process mediated by IDO and PGE2. MSCs also inhibit the differentiation of monocytes into DCs via the release of IL-6 and IL-10. Additionally, MSCs can drive DCs towards an IL-10-producing tolerogenic phenotype through the activation of Notch signalling. MSCs also direct macrophages towards an anti-inflammatory phenotype (M2) via the action of IL-10. IL-10 production from via different pathways triggers the generation of Tregs.

that TGF- $\beta$-inactivated hUC-MSCs lacked the ability to generate Tregs in vitro (95). Finally, TGF- $\beta$ was also reported to promote anti-inflammatory M2 macrophages (96).

\section{Indoleamine-2, 3-Dioxygenase (IDO)}

Using Western blot analysis, Meisel et al. demonstrated that hMSCs do not constitutively express IDO. Instead, IDO protein expression by MSCs is induced by IFN- $\gamma$ in a dose-dependent manner (97). Mounayar and colleagues have identified phosphoinositide 3-kinase alpha $(\mathrm{PI} 3 \mathrm{~K} \alpha)$ as a major regulatory of IFN- $\gamma$-induced IDO expression by MSCs. This effect was shown to be mediated via the signal transducer and activator of transcription 1 (STAT1) (98). Of interest, Li et al. observed that while low concentrations of cytokines were sufficient to upregulate chemokine secretion, they were not enough to induce significant expression of IDO in mammals and nitric oxide (NO) in rodents (99). Chemokine-recruited lymphocytes accumulate in the vicinity of MSCs without being suppressed. According to Wang et al., MSCs can be immunosuppressive in strong inflammatory conditions. Paradoxically, with weak inflammation, their immunomodulatory function is abrogated and immune responses are enhanced (100). Accordingly, the authors described IDO levels as an "on-off switch" dictating the immunomodulatory outcome of MSCs. IFN- $\gamma$-mediated IDO expression by hAT-MSCs resulted in the inhibition of lymphocyte proliferation (101). IDO-mediated tryptophan depletion, via its catabolic conversion to kynurenine, was shown to be responsible for this inhibition (102). Abrogation of NK cell proliferation and maturation was also confirmed to be the result of MSC-derived IDO (103). In an experimental study by Ge et al., MSC infusion 24 hours post-allogeneic kidney transplantation in mice enhanced graft tolerance. The tolerant recipients exhibited an increase in kynurenine levels as well as high frequencies of tolerogenic DCs and Tregs. On the other hand, renal allograft recipients treated with MSC infusion concomitant with the IDO inhibitor 1-methyltryptophan did not attain graft tolerance. These findings confirm that functional IDO was necessary to induce the observed immunomodulation (104).

\section{Nitric Oxide (NO)}

Inducible NO synthase (iNOS) has been detected in MSCs. In the presence of activated $\mathrm{T}$ cells, there is notable dose-dependent production of NO by MSCs. NO-mediated suppression of T cell proliferation is the result of the inhibition of STAT-5 phosphorylation, which is required for cell proliferation. In Transwell experiments, this suppression was reduced, suggesting that this function depends on cell-to-cell contact (105). It is worth noting that MSC-mediated immunosuppression is not similar among different species. While this effect is mediated by NO in mice, it is mediated by IDO in humans (106).

\section{Prostaglandin E2 (PGE2)}

Baratelli and colleagues demonstrated that PGE2 induced expression of the Treg-specific transcription factor FOXP3 in 
$\mathrm{CD} 4{ }^{+} \mathrm{CD} 25^{+}$Tregs (107). English et al. reported that the action of PGE2 was preceded by cell-to-cell contact (63). The resulting Tregs acted similarly to naturally developed nTregs. PGE2 was also shown to be involved in the suppression of monocytic differentiation into DCs (108), as well as the inhibition of proliferation and cytotoxic activity of NK cells (109).

\section{Interleukin 10 (IL-10)}

IL-10 is another main immunosuppressive cytokine associated with MSCs, and its expression can be further enhanced by PGE2 (110). IL-10 was demonstrated to inhibit APC maturation, suppress Th17 generation and promote Treg proliferation (111).

\section{Programmed Death Ligands 1 and 2}

\section{(PD- $\mathrm{L}_{1}$ and PD- $\mathrm{L}_{2}$ )}

MSCs constitutively express the programmed death ligands $\mathrm{PD}-\mathrm{L}_{1}$ and $\mathrm{PD}-\mathrm{L}_{2}$, which are upregulated in the presence of inflammatory cytokines. Through cognate contact between $\mathrm{PD}-\mathrm{L}_{1}-$ and $\mathrm{PD}-\mathrm{L}_{2}$-expressing $\mathrm{MSCs}$ and $\mathrm{PD}$-1-expressing lymphocytes, the kinase activity of the $\mathrm{T}$ cell receptor is disrupted (112). This disruption inhibits $\mathrm{T}$ cell proliferation and induces $\mathrm{T}$ cell anergy and apoptosis $(113,114)$. Davies et al. provided evidence that in addition to the surface expression of $\mathrm{PD}-\mathrm{L}_{1}$ and $\mathrm{PD}-\mathrm{L}_{2}$ by MSCs, these factors are also secreted into the microenvironment upon stimulation with IFN- $\gamma$ and TNF- $\alpha$. Based on these findings, it was suggested that stimulated MSCs can exert their immunosuppressive function by cell contact, as well as by contact-independent pathways (115). Fiorina and associates shed light on the important role of $\mathrm{PD}-\mathrm{L}_{1}$ in immunomodulation. They reported that, compared to NOD MSCs, BALB/c or NOR (NOD-related, diabetic resistant mice) MSCs express higher levels of PD- $\mathrm{L}_{1}$. Administration of $\mathrm{BALB} / \mathrm{c}$ MSCs achieved temporary reversal of hyperglycemia in $90 \%$ of NOD mice. However, in this setting, soft tissue and visceral tumor were observed in the recipient NOD mice (116). In a further investigation by Jurewicz et al., NOR MSCs were able to suppress NOD $\mathrm{CD}^{+} \mathrm{T}$ cell proliferation via $\mathrm{PD}-\mathrm{L}_{1}$, and inhibit the generation of proinflammatory DCs through an IL-6-dependent mechanism. NOR MSC-based treatment of experimental type 1 diabetic NOD mice resulted in reversal of hyperglycemia. It was concluded that congenic MSC therapy can be useful in future clinical trials for treatment of type 1 diabetes (117). Using human placenta-derived MSCs (hP-MSCs), Gu and associates observed that these cells expressed not only PD-L but also Fas ligands (FasL) (118). Neutralizing antibodies against PD$\mathrm{L}_{1}$ and FasL significantly interfered with the suppressive effect of hP-MSCs on $\mathrm{T}$ cell proliferation. However, anti-FasL but not anti-PD- $\mathrm{L}_{1}$ antibodies suppressed activated $\mathrm{T}$ cell apoptosis. The authors concluded that both ligands played significant but different roles in hP-MSC-mediated immunomodulation.

\section{Cell-to-Cell Contact: Adhesion Molecules and Chemokines}

Interactions between cell surface receptors and their ligands are central for cell attachment, communication and function. Under inflammatory conditions, in addition to secreting anti- inflammatory cytokines and soluble factors, MSCs express adhesion molecules and chemokines that enable them to establish cell-to-cell contact with lymphocytes (119). Majumdar et al. identified distinct cell surface molecules expressed on MSCs, including intracellular adhesion molecule (ICAM)-1 and ICAM-2 and vascular cell adhesion molecule (VCAM)-2 (120). Stimulation of MSCs with IFN- $\gamma$ and TNF- $\alpha$ upregulated their ICAM-1 surface expression, increasing their affinity towards activated $\mathrm{T}$ cells. Working with murine BMMSCs, Ren and associates observed that stimulating MSCs with IFN- $\gamma$ with TNF- $\alpha$ or IL- 1 upregulated ICAM-1, as well as VCAM-1, increasing their affinity towards activated $\mathrm{T}$ cells. Genetic deletion or functional blockade of these adhesion molecules abrogated the immunosuppressive effect of MSCs in vitro and in vivo (121). In addition, stimulation of MSCs was shown to induce robust expression of several chemokines (122), of which the majority were CXC chemokine receptor 3 (CXCR3) and CC chemokine receptor 5 (CCR5) ligands. Using time-lapse microscopy, it was proven that activated $\mathrm{T}$ cells accumulate in close proximity to cytokine-activated MSCs. Pharmacological or genetic blockade of CXCR3 or CCR5 prevented cell migration and inhibited MSC-induced immunosuppression.

Recent studies have shed more light on mechanisms involved in contact-dependent signalling between hAT-MSCs and activated $\mathrm{T}$ cells. Matula et al. provided evidence that the exchange of cytoplasmic material between these cells was mediated by tunnelling nanotubes and extracellular vesicles exclusively derived from $\mathrm{T}$ cells (123). As a result, the properties of MSCs shift towards an anti-inflammatory phenotype associated with the production of soluble immunosuppressive molecules, including PGE2.

In summary, soluble factors together with cell-to-cell contact create a microenvironment in which the immunomodulatory functions of MSCs are rendered more pronounced.

\section{FACTORS INFLUENCING THE IMMUNOMODULATORY FUNCTIONS OF MSCs}

Numerous factors can alter the immune properties of MSCs, which may explain, at least in part, the contrasting results reported in the literature. In addition, it would be valuable to identify these variables to circumvent those that hinder and exploit others that promote the immunomodulatory properties of MSCs if an application of this function is contemplated.

MSCs derived from different sources exhibit distinct expansion, differentiation, paracrine and immune characteristics. In a comparative study, Ribeiro and colleagues evaluated the immunosuppressive functions of AT-MSCs, BMMSCs and umbilical cord matrix-derived MSCs (UCM-MSCs). AT-MSCs were shown to pose a stronger inhibitory effect on $\mathrm{T}$ cell proliferation and blocked $\mathrm{T}$ cell activation at an earlier stage than BM-MSCs or UCM-MSCs (124). Additionally, several publications have reported that AT-MSCs are more potent 
suppressors of DC differentiation and exhibit a higher immunomodulatory capacity than BM-MSCs (125, 126). Valencia et al. compared the immunomodulatory properties of AT-MSCs and BM-MSCs from the same donor to overcome any heterogeneity resulting from donor-to-donor variations. The researchers concluded that AT-MSCs and BM-MSCs have comparable immunomodulatory features. Selection of either cell type would, therefore, depend on other factors, including availability and MSC density in the tissue samples (127).

Donor age also has an impact on the therapeutic potential of derived MSCs. The yield of hMSCs obtained by marrow aspiration is likely to decline with age. MSCs derived from younger individuals were proven to have higher proliferation rates with lower levels of oxidative stress-mediated damage (128). Wagner and associates maintained that the changes upon ageing were associated with the replicative senescence of MSCs (129).

In a study by Serena et al., the immunomodulatory capacities of AT-MSCs derived from lean, obese and diabetic donors were compared. They reported that obese-derived AT-MSCs or those from type 2 diabetic patients were less effective in suppressing lymphocytic proliferation, inducing M2 macrophages and releasing TGF- $\beta$ than those from healthy controls (130). Metabolic changes resulting from the diabetic microenvironment can provide an explanation (131). This conclusion suggests the question of whether such changes can affect the therapeutic function and immunomodulatory properties of MSC-derived IPCs after transplantation in diabetic patients. In an experimental study by our group, chemically-induced diabetes in nude mice did not interfere with the in vivo maturation of transplanted hBM-MSC-derived IPCs (132).

The methods utilized for MSC isolation, expansion and preservation can also significantly affect the quality and potential therapeutic efficacy of MSCs. Yoo et al. compared the conventional gradient centrifugation technique with a subfractionation culture method and showed that cloned hMSCs were more efficient than conventionally isolated MSCs in regulating graft-versus-host disease (133). Optimization of MSC culture conditions also has a critical impact on MSC functionality. MSCs cultured under hypoxic conditions are forced to switch to anaerobic metabolism. The resulting lactate directs macrophages towards an anti-inflammatory phenotype (134). It was also noted that MSCs in 3D culture exhibit stronger immunosuppressive properties, and the secretion of immunomodulatory molecules was enhanced (135). Evidence has shown that MSCs expanded in media containing fetal bovine serum can develop anti-fetal calf serum antibodies upon in vivo application (136). It is also worth noting that MSCs expanded in platelet lysate showed decreased inhibitory capacity on T and NK cell proliferation (137). In a study by Liu et al., the relationship between MSC passage number and their immunomodulatory function was investigated (138). The authors demonstrated that with increasing passage number, there was a gradual loss of MSC immunomodulatory properties. These changes became statistically significant after passage 10. Cryopreservation, followed by thawing before utilization, could also result in low cell viability or induce heat shock responses that may account for the reduced modulatory functionality of MSCs (139).

The chosen route of administration may also influence the immune function of MSCs. The immunogenicity of allogeneic MSCs transplanted by different routes in diabetic mice was compared by $\mathrm{Gu}$ et al. The researchers observed that cells transplanted under the pancreatic capsule evoked an immune reaction. Conversely, MSCs infused through the tail vein retained their immunosuppressive capabilities (140).

\section{ENHANCEMENT OF THE IMMUNOMODULATORY FUNCTIONS OF MSCs}

There have been increasing attempts to enhance the immunomodulatory functions of MSCs and achieve improved therapeutic outcomes $(141,142)$. These measures include in vitro pretreatment, coadministration of mTOR inhibitors, Treg utilization and gene manipulation.

Since the immunosuppressive properties of MSCs are triggered in an inflammatory environment, preconditioning with proinflammatory cytokines has been used to enhance these functions. Increased secretion of PGE2 and TGF- $\beta$ and induced expression of PD-L1 were observed in IFN- $\gamma$-primed MSCs $(143,144)$. On this basis, IFN- $\gamma$-conditioned MSCs were experimentally used to treat some immune-associated disorders $(145,146)$. Oliveira and associates evaluated the survival of untreated allogeneic MSCs compared to those pretreated with IFN- $\gamma$ and TNF- $\alpha$ following transplantation under the renal capsule of immunocompetent mice (147). In vivo, both groups of cells provoked an immune response with inflammatory cell infiltration at the transplantation site and consequent graft loss. Combined transplantation of preactivated cells and allogeneic islets was associated with marginal prolongation of graft survival. Yoshihara and associates differentiated human iPSCs into what they termed human islet-like organoids (HILOs). Immune-evasive HILOs were initially generated by transfection with a $\mathrm{PD}-\mathrm{L}_{1}$-expressing lentivirus, and later by short repeated exposures to IFN- $\gamma$ to induce sustained expression of PD- $\mathrm{L}_{1}$. Transplantation of these HILOs in immunecompetent streptozotocin (STZ)-induced diabetic mice reduced blood glucose levels for more than 40 days, while the functional efficacy of untreated HILOs was progressively lost. Similar results were seen upon transplantation in diabetic humanized mice. Surgical removal of the cell-bearing kidneys was followed by an abrupt loss of glycaemic control. Examination of the explanted specimens revealed an increase in the number of insulinexpressing cells and a decrease in lymphocytic infiltration. The authors maintained that this approach could provide a promising alternative to cadaveric-dependent sources for the treatment of diabetes (148). On the other hand, Sivanathan and associates pointed out that the upregulated expression of $\mathrm{MHC}$ in allogeneic IFN- $\gamma$-stimulated MSCs may boost their 
immunogenicity and dampen their immunomodulatory functions (149). Coadministration of immunosuppressive drugs, rapamycin in particular, may offset this phenomenon in vivo.

Battalgia and colleagues reported that rapamycin, an mTOR inhibitor, selectively expanded murine nTregs in vitro. The expanded nTregs suppressed the proliferation of syngeneic $\mathrm{T}$ cells in vitro and prevented allograft rejection in vivo (150). Wang and colleagues provided evidence that rapamycin enhanced the immunomodulatory functions of MSCs by upregulating COX-2 expression and inducing PGE2 release. The authors noted that prolonged exposure to rapamycin did not support this effect and suggested that only short-term incubation of MSCs with rapamycin could improve immunomodulation and represent a novel therapeutic tool (151).

The use of Tregs can provide an additional tool for enhanced immunomodulation. Tregs are usually isolated from peripheral blood and expanded ex vivo (152). By providing a tool to generate location-specific or antigen-specific Tregs, chimeric antigen receptor (CAR) gene engineering can potentially boost the specific suppressive capacity of Tregs, circumventing offtarget immunosuppression (153).

Gene manipulation involves transduction of the appropriate gene or genetic engineering. Garcia-Ocana and associates transduced the hepatocyte growth factor gene via an adenoviral vector into murine islets in vitro. Upon transplantation of these cells in STZ-induced diabetic mice, improvements in graft survival and blood glucose control were observed (154). Qi et al. used a lentiviral vector to overexpress the FOXP3 gene in rat MSCs. Following liver transplantation,

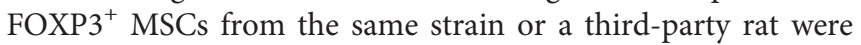
intravenously infused. The authors reported that FOXP3 ${ }^{+}$MSCs induced liver allograft tolerance (155). Again, Niu and colleagues prepared syngeneic rat MSCs by transduction with IL-10. These cells were intravenously injected into a rat model after liver transplantation. The results suggested that IL-10-engineered cells had the potential to overcome rejection of the transplanted liver (156). Collectively, these results indicate that the engraftment of transduced MSCs can promote immunomodulation and support cell or organ transplantation. However, these procedures rely on the use of viral vectors, which impose the limitations of possible oncogene transactivation and a lack of physiological expression to allow monitoring.

Recently, gene editing has emerged as a powerful alternative approach (157). Moghadan and associates developed a CRISPRbased system that could effectively modulate the immune responses of the host (158). To this end, the authors made use of the transcriptional repressors heterochromatin protein 1 $(\mathrm{HPI} \alpha)$ and Kruppel-associated box protein (KRAB). With a gRNA aptamer, these repressors were fused to a nucleasecompetent CRISPR containing a truncated gRNA. This complex could repress the myeloid differentiation protein (Myd88) gene, which encodes the Myd88 protein that is involved in innate signalling. This system was shown to effectively downregulate IgG production against an adeno- associated virus in mice. The authors concluded that CRISPRmediated suppression of endogenous Myd88 could modulate host immune responses and be used as a therapeutic modality for immune modulation.

The inhibitory CD47 ligand is an efficient immunomodulator and has been proven to be upregulated in cancer $(159,160)$. In a series of recent experiments, Deuse et al. noted that CD47 overexpression prevented NK cells from killing MHC class Iand II-deficient targets in mice (161). The researchers then provided evidence that the immune-inhibitory function of CD47 is exerted by ligation to signal regulatory protein $\alpha$ $(\operatorname{SIRP} \alpha)$ on NK cells. They also observed that $\operatorname{Sirp} \alpha$ expression in murine NK cells and its CD47 binding were strongly upregulated by IL-2 in a dose-dependent manner. Similar observations were reported in human NK cells. Since blocking either CD47 or SIRP $\alpha$ rendered human HLA-deficient endothelial cells susceptible to primary NK cell cytotoxicity, it was concluded that in humans, $\operatorname{SIRP} \alpha$ was essential for the transmission of the CD47-induced inhibitory signal to NK cells. The authors estimated the necessary threshold for CD4 expression that could inhibit innate immune responses to be $\approx 3.5$-fold higher than basal values. Furthermore, cloned rhesus monkey CD47 (rhCD47) was transduced by a lentivirus into human HLA-deficient endothelial cells. In vitro, human cells were spared the deleterious effects of rhesus NK cells and macrophages. This finding demonstrated that rhCD47 expression could inhibit rhesus monkey-derived innate cells in a xenogeneic setting. Collectively, these experiments suggest that the generation of non-immunogenic stem cells is possible. Such cells can evade immune responses and differentiate into functional somatic cells following transplantation. Genetically modified cells, however, carry potential risks. It is important to demonstrate that in addition to the expected benefits, these cells do not give rise to tumorigenic or otherwise harmful cells (32).

Notably, MSC-derived exosomes transfer biomolecules to target tissues or cells. The intrinsic contents of exosomes are determined by the biological components of the parent cell cytoplasm (162). Accordingly, preconditioning or genetic engineering of MSCs can improve the therapeutic efficacy of their derived exosomes. Coadministration of these exosomes combined with allogeneic MSC-derived IPCs could provide an additional tool for enhancing their immunomodulatory properties.

In a different approach, Al-Daccak and Charron suggested that banking allogeneic stem cells could provide an opportunity to select HLA-compatible donors and avoid detrimental mismatches (163). The size of such a donor bank would depend on the frequencies of HLA haplotypes. Within the same ethnic background, it is estimated that storing $\approx 100$ samples would allow for the selection of suitable donors. The authors also proposed identifying, those with an immunomodulatory benefit among the permissive matches. Guan et al. suggested that the potency of the immunomodulatory capacity of MSCs can be evaluated (164). Following pretreatment with IFN- $\gamma$, the expression of intracellular IDO and surface expression of $\mathrm{PD}-\mathrm{L}_{1}$ can be determined. Choosing donors with the highest expression levels is an additional optimization tool 
(165). Moreover, a Luminex-based solid-phase assay could be used to detect and minimize the risk of donor-specific antibodies (166). Collectively, these measures guide the identification of immune-educated, low-risk, high-benefit donors.

\section{CONCLUDING REMARKS}

- Pluripotent stem cell-derived IPCs are immunogenic. Their transplantation requires encapsulation within an immunoisolation device and has inherent limitations.

- It is possible, though unlikely, to obtain autologous MSCs from type 1 diabetic patients if the patient's own umbilical cord-derived MSCs have been previously stored.

- In the clinical setting, the use of allogeneic cells is more practical. Human AT-MSCs are widely available from cosmetic surgeries and should not be wasted. These cells can be stored, and their HLA type can be identified for selecting a compatible donor.

- To date, studies of the immunogenicity of allogeneic hMSCderived IPCs have been rare, confusing and non-informative. Transplantation into a humanized mouse model can provide important clues.

- Based on experiences with allogeneic cardiac progenitors, the selection of low-risk and high-benefit donor cells should be explored when cell therapy for T1DM is contemplated.

- The pre-existing destructive autoimmune environment in T1DM should not be overlooked. In this context, the immunomodulatory properties of allogeneic hMSC-derived IPCs can be enhanced by pretreatment with inflammatory cytokines. In addition, the use of adjuvant immunosuppression may be necessary. Sirolimus, an mTOR inhibitor, would be the agent of choice. In addition to its well-known immunosuppressive effect, sirolimus can also enhance

\section{REFERENCES}

1. Dominici ML, Le Blanc K, Mueller I, Slaper-Cortenbach I, Marini FC, Krause DS, et al. Minimal Criteria for Defining Multipotent Mesenchymal Stromal Cells. The International Society for Cellular Therapy Position Statement. Cytotherapy (2006) 8(4):315-7. doi: 10.1080/14653240600855905

2. Guo QS, Zhu MY, Wang L, Fan XJ, Lu YH, Wang ZW, et al. Combined Transfection of the Three Transcriptional Factors, pdx-1, neurod1, and MafA, Causes Differentiation of Bone Marrow Mesenchymal Stem Cells Into Insulin-Producing Cells. Exp Diabetes Res (2012) 2012:672013. doi: $10.1155 / 2012 / 672013$

3. Ma S, Viola R, Sui L, Cherubini V, Barbetti F, Egli D. $\beta$ Cell Replacement After Gene Editing of a Neonatal Diabetes-Causing Mutation at the Insulin Locus. Stem Cell Rep (2018) 11(6):1407-15. doi: 10.1016/j.stemcr.2018.11.006

4. Sun Y, Chen L, Hou XG, Hou WK, Dong JJ, Sun L, et al. Differentiation of Bone Marrow-Derived Mesenchymal Stem Cells From Diabetic Patients Into Insulin-Producing Cells In Vitro. Chin Med J (Engl) (2007) 120(9):7716. doi: 10.1097/00029330-200705010-00007

5. Gabr MM, Zakaria MM, Refaie AF, Ismail AM, Abou-El-Mahasen MA, Ashamallah SA, et al. Insulin-Producing Cells From Adult Human Bone Marrow Mesenchymal Stem Cells Control Streptozotocin-Induced Diabetes in Nude Mice. Cell Transplant (2013) 22(1):133-45. doi: 10.3727/ 096368912 X647162 immunomodulation through the induction of COX-2 and PGE2 expression.

- Gene manipulation promises the generation of stem cells that can evade immune recognition, which, provided that they do not induce untoward effects, presents an alternative enhancement strategy.

- In any case, the ultimate cell therapy for type 1 diabetic patients should be as good as or better than the ever improving closed-loop insulin delivery systems.

\section{AUTHOR CONTRIBUTIONS}

AR: Revised the manuscript and arranged the references.BE: Edited the manuscript and verified the references. MK: Revised the manuscript and added to the section on macrophages and cell-to-cell contact. SK: Carried out the immunohistological study. AI: Revised the section on immunomodulation. RM: Revised the manuscript and edited the section on the special case of stem cell-derived IPCs. MG: Wrote the original draft and revised the final manuscript. All authors contributed to the article and approved the submitted version.

\section{ACKNOWLEDGMENTS}

Special thanks to Prof. Xian Chang Li, Director, Immunobiology \& Transplant Science Center, Houston Methodist, Weill Cornell Medical College, USA, for proofreading the manuscript. The authors would also like to thank Mrs. Fathia Gado for her excellent immunolabelling work and Mrs. Ahlam Saad and Miss Afnan Mansour for their excellent secretarial work.

6. Czubak P, Bojarska-Junak A, Tabarkiewicz J, Putowski L. A Modified Method of Insulin Producing Cells' Generation From Bone Marrow-Derived Mesenchymal Stem Cells. J Diabetes Res (2014) 2014:628591. doi: 10.1155/2014/628591

7. Khorsandi L, Khodadadi A, Nejad-Dehbashi F, Saremy S. ThreeDimensional Differentiation of Adipose-Derived Mesenchymal Stem Cells Into Insulin-Producing Cells. Cell Tissue Res (2015) 361(3):745-53. doi: 10.1007/s00441-015-2140-9

8. Ghoneim MA, Refaie AF, Elbassiouny BL, Gabr MM, Zakaria MM. From Mesenchymal Stromal/Stem Cells to Insulin-Producing Cells: Progress and Challenges. Stem Cell Rev Rep (2020) 16(6):1156-72. doi: 10.1007/s12015020-10036-3

9. Bartholomew A, Sturgeon C, Siatskas M, Ferrer K, McIntosh K, Patil S, et al. Mesenchymal Stem Cells Suppress Lymphocyte Proliferation In Vitro and Prolong Skin Graft Survival In Vivo. Exp Hematol (2002) 30(1):42-8. doi: $10.1016 / \mathrm{s} 0301-472 \mathrm{x}(01) 00769-\mathrm{x}$

10. Tse WT, Pendleton JD, Beyer WM, Egalka MC, Guinan EC. Suppression of Allogeneic T-cell Proliferation by Human Marrow Stromal Cells: Implications in Transplantation. Transplantation (2003) 75(3):389-97. doi: 10.1097/01.TP.0000045055.63901.A9

11. Le Blanc K, Tammik C, Rosendahl K, Zetterberg E, Ringdén O. HLA Expression and Immunologic Properties of Differentiated and Undifferentiated Mesenchymal Stem Cells. Exp Hematol (2003) 31 (10):890-6. doi: 10.1016/s0301-472x(03)00110-3 
12. Rasmusson I. Immune Modulation by Mesenchymal Stem Cells. Exp Cell Res (2006) 312(12):2169-79. doi: 10.1016/j.yexcr.2006.03.019

13. Bifari F, Lisi V, Mimiola E, Pasini A, Krampera M. Immune Modulation by Mesenchymal Stem Cells. Transfus Med Hemother (2008) 35(3):194-204. doi: 10.1159/000128968

14. Zhang X, Tang T, Shi Q, Fernandes JC, Dai K. The Immunologic Properties of Undifferentiated and Osteogenic Differentiated Mouse Mesenchymal Stem Cells and Its Potential Application in Bone Regeneration. Immunobiology (2009) 214(3):179-86. doi: 10.1016/j.imbio.2008.07.030

15. Le Blanc K, Rasmusson I, Sundberg B, Götherström C, Hassan M, Uzunel M, et al. Treatment of Severe Acute Graft-Versus-Host Disease With Third Party Haploidentical Mesenchymal Stem Cells. Lancet (2004) 363 (9419):1439-41. doi: 10.1016/S0140-6736(04)16104-7

16. Fang B, Li N, Song Y, Li J, Zhao RC, Ma Y. Cotransplantation of Haploidentical Mesenchymal Stem Cells to Enhance Engraftment of Hematopoietic Stem Cells and to Reduce the Risk of Graft Failure in Two Children With Severe Aplastic Anemia. Pediatr Transplant (2009) 13 (4):499-502. doi: 10.1111/j.1399-3046.2008.01002.x

17. Connick P, Kolappan M, Crawley C, Webber DJ, Patani R, Michell AW, et al. Autologous Mesenchymal Stem Cells for the Treatment of Secondary Progressive Multiple Sclerosis: An Open-Label Phase 2a Proof-of-Concept Study. Lancet Neurol (2012) 11(2):150-6. doi: 10.1016/S1474-4422(11)70305-2

18. Wang L, Wang L, Cong X, Liu G, Zhou J, Bai B, et al. Human Umbilical Cord Mesenchymal Stem Cell Therapy for Patients With Active Rheumatoid Arthritis: Safety and Efficacy. Stem Cells Dev (2013) 22(24):3192-202. doi: $10.1089 /$ scd.2013.0023

19. Forbes GM, Sturm MJ, Leong RW, Sparrow MP, Segarajasingam D, Cummins AG, et al. A Phase 2 Study of Allogeneic Mesenchymal Stromal Cells for Luminal Crohn's Disease Refractory to Biologic Therapy. Clin Gastroenterol Hepatol (2014) 12(1):64-71. doi: 10.1016/j.cgh.2013.06.021

20. Wang D, Zhang H, Liang J, Li X, Feng X, Wang H, et al. Allogeneic Mesenchymal Stem Cell Transplantation in Severe and Refractory Systemic Lupus Erythematosus: 4 Years of Experience. Cell Transplant (2013) 22 (12):2267-77. doi: 10.3727/096368911X582769c

21. Nauta AJ, Westerhuis G, Kruisselbrink AB, Lurvink EG, Willemze R, Fibbe WE. Donor-Derived Mesenchymal Stem Cells are Immunogenic in an Allogeneic Host and Stimulate Donor Graft Rejection in a Nonmyeloablative Setting. Blood (2006) 108(6):2114-20. doi: 10.1182/ blood-2005-11-011650

22. Ankrum JA, Ong JF, Karp JM. Mesenchymal Stem Cells: Immune Evasive, Not Immune Privileged. Nat Biotechnol (2014) 32(3):252-60. doi: 10.1038/ nbt. 2816

23. Berglund AK, Fortier LA, Antczak DF, Schnabel LV. Immunoprivileged No More: Measuring the Immunogenicity of Allogeneic Adult Mesenchymal Stem Cells. Stem Cell Res Ther (2017) 8(1):288. doi: 10.1186/s13287-017-0742-8

24. Poncelet AJ, Vercruysse J, Saliez A, Gianello P. Although Pig Allogeneic Mesenchymal Stem Cells are Not Immunogenic In Vitro, Intracardiac Injection Elicits an Immune Response In Vivo. Transplantation (2007) 83 (6):783-90. doi: 10.1097/01.tp.0000258649.23081.a3

25. Lohan P, Coleman CM, Murphy JM, Griffin MD, Ritter T, Ryan AE. Changes in Immunological Profile of Allogeneic Mesenchymal Stem Cells After Differentiation: Should We be Concerned? Stem Cell Res Ther (2014) 5 (4):99. doi: $10.1186 /$ scrt488

26. Ryan AE, Lohan P, O'Flynn L, Treacy O, Chen X, Coleman C, et al. Chondrogenic Differentiation Increases Antidonor Immune Response to Allogeneic Mesenchymal Stem Cell Transplantation. Mol Ther (2014) 22 (3):655-67. doi: 10.1038/mt.2013.261

27. Yang XF, Chen T, Ren LW, Yang L, Qi H, Li FR. Immunogenicity of InsulinProducing Cells Derived From Human Umbilical Cord Mesenchymal Stem Cells. Exp Ther Med (2017) 13(4):1456-64. doi: 10.3892/etm.2017.4096

28. Hassanin OM, El-Masry TM, Abu-Zahra FA, El-Adawy S, Abdellah AM. Immune-Modulatory Changes After Transplantation Therapy of Insulin Producing Cells Derived From Wharton's Jelly Human Umbilical CordMesenchymal Stem Cells in Diabetes Induced Rats. Egypt J Immunol (2019) 26(1):55-67.

29. van der Torren CR, Zaldumbide A, Duinkerken G, Brand-Schaaf SH, Peakman M, Stangé G, et al. Immunogenicity of Human Embryonic Stem Cell-Derived Beta Cells. Diabetologia (2017) 60(1):126-33. doi: 10.1007/s00125-016-4125-y
30. Sordi V, Pellegrini S, Piemonti L. Immunological Issues After Stem Cell-Based $\beta$ Cell Replacement. Curr Diabetes Rep (2017) 17(9):68. doi: 10.1007/s11892-017-0901-4

31. Wood KJ, Issa F, Hester J. Understanding Stem Cell Immunogenicity in Therapeutic Applications. Trends Immunol (2016) 37(1):5-16. doi: 10.1016/ j.it.2015.11.005

32. Melton D. The Promise of Stem Cell-Derived Islet Replacement Therapy. Diabetologia (2021) 64:1030-6. doi: 10.1007/s00125-020-05367-2

33. Mohammadi N, Mardomi A, Hassannia H, Enderami SE, Ranjbaran H, Rafiei A, et al. Mouse Bone Marrow-Derived Mesenchymal Stem Cells Acquire Immunogenicity Concurrent With Differentiation to InsulinProducing Cells. Immunobiology (2020) 225(5):151994. doi: 10.1016/ j.imbio.2020.151994

34. Martinov T, Fife BT. Type 1 Diabetes Pathogenesis and the Role of Inhibitory Receptors in Islet Tolerance. Ann NY Acad Sci (2020) 1461 (1):73-103. doi: $10.1111 /$ nyas.14106

35. Roep BO, Thomaidou S, van Tienhoven R, Zaldumbide A. Type 1 Diabetes Mellitus as a Disease of the $\beta$-Cell (Do Not Blame the Immune System)? Nat Rev Endocrinol (2021) 17(3):150-61. doi: 10.1038/s41574-020-00443-4

36. Vaarala O. Gut Microbiota and Type 1 Diabetes. Rev Diabetes Stud (2012) 9 (4):251-9. doi: 10.1900/RDS.2012.9.251

37. Eizirik DL, Colli ML, Ortis F. The Role of Inflammation in Insulitis and Beta-Cell Loss in Type 1 Diabetes. Nat Rev Endocrinol (2009) 5(4):219-26. doi: 10.1038/nrendo.2009.21

38. Wenzlau JM, Hutton JC. Novel Diabetes Autoantibodies and Prediction of Type 1 Diabetes. Curr Diabetes Rep (2013) 13(5):608-15. doi: 10.1007/ s11892-013-0405-9

39. Bloem SJ, Roep BO. The Elusive Role of B Lymphocytes and Islet Autoantibodies in (Human) Type 1 Diabetes. Diabetologia (2017) 60 (7):1185-89. doi: 10.1007/s00125-017-4284-5

40. Purwana I, Zheng J, Li X, Deurloo M, Son DO, Zhang Z, et al. GABA Promotes Human $\beta$-Cell Proliferation and Modulates Glucose Homeostasis. Diabetes (2014) 63(12):4197-205. doi: 10.2337/db14-0153

41. Hemeda H, Jakob M, Ludwig AK, Giebel B, Lang S, Brandau S. Interferon- $\gamma$ and Tumor Necrosis Factor- $\alpha$ Differentially Affect Cytokine Expression and Migration Properties of Mesenchymal Stem Cells. Stem Cells Dev (2010) 19 (5):693-706. doi: 10.1089/scd.2009.0365

42. Behm C, Blufstein A, Gahn J, Nemec M, Moritz A, Rausch-Fan X, et al. Cytokines Differently Define the Immunomodulation of Mesenchymal Stem Cells From the Periodontal Ligament. Cells (2020) 9(5):1222. doi: 10.3390/ cells 9051222

43. Di Nicola M, Carlo-Stella C, Magni M, Milanesi M, Longoni PD, Matteucci P, et al. Human Bone Marrow Stromal Cells Suppress T-Lymphocyte Proliferation Induced by Cellular or Nonspecific Mitogenic Stimuli. Blood (2002) 99(10):3838-43. doi: 10.1182/blood.v99.10.3838

44. Le Blanc K, Tammik L, Sundberg B, Haynesworth SE, Ringdén O. Mesenchymal Stem Cells Inhibit and Stimulate Mixed Lymphocyte Cultures and Mitogenic Responses Independently of the Major Histocompatibility Complex. Scand J Immunol (2003) 57(1):11-20 doi: 10.1046/j.1365-3083.2003.01176.x

45. Aggarwal S, Pittenger MF. Human Mesenchymal Stem Cells Modulate Allogeneic Immune Cell Responses. Blood (2005) 105(4):1815-22. doi: 10.1182/blood-2004-04-1559

46. Zhao Q, Ren H, Han Z. Mesenchymal Stem Cells: Immunomodulatory Capability and Clinical Potential in Immune Diseases. J Cell Immunother (2016) 2(1):3-20. doi: 10.1016/j.jocit.2014.12.001

47. Glennie S, Soeiro I, Dyson PJ, Lam EW, Dazzi F. Bone Marrow Mesenchymal Stem Cells Induce Division Arrest Anergy of Activated T Cells. Blood (2005) 105(7):2821-7. doi: 10.1182/blood-2004-09-3696

48. Shi M, Liu ZW, Wang FS. Immunomodulatory Properties and Therapeutic Application of Mesenchymal Stem Cells. Clin Exp Immunol (2011) 164(1):18. doi: 10.1111/j.1365-2249.2011.04327.x

49. Plumas J, Chaperot L, Richard MJ, Molens JP, Bensa JC, Favrot MC Mesenchymal Stem Cells Induce Apoptosis of Activated T Cells. Leukemia (2005) 19(9):1597-604. doi: 10.1038/sj.leu.2403871

50. Akiyama K, Chen C, Wang D, Xu X, Qu C, Yamaza T, et al. MesenchymalStem-Cell-Induced Immunoregulation Involves FAS-Ligand-/FASMediated T Cell Apoptosis. Cell Stem Cell (2012) 10(5):544-55 doi: 10.1016/j.stem.2012.03.007 
51. Duffy MM, Ritter T, Ceredig R, Griffin MD. Mesenchymal Stem Cell Effects on T-Cell Effector Pathways. Stem Cell Res Ther (2011) 2(4):34. doi: 10.1186/ scrt75

52. Luz-Crawford P, Kurte M, Bravo-Alegría J, Contreras R, Nova-Lamperti E, Tejedor G, et al. Mesenchymal Stem Cells Generate a CD4+CD25+Foxp3+ Regulatory T Cell Population During the Differentiation Process of Th1 and Th17 Cells. Stem Cell Res Ther (2013) 4(3):65. doi: 10.1186/scrt216

53. Ghannam S, Pène J, Moquet-Torcy G, Jorgensen C, Yssel H. Mesenchymal Stem Cells Inhibit Human Th17 Cell Differentiation and Function and Induce a T Regulatory Cell Phenotype. J Immunol (2010) 185(1):302-12. doi: 10.4049/jimmunol.0902007

54. Abumaree M, Al Jumah M, Pace RA, Kalionis B. Immunosuppressive Properties of Mesenchymal Stem Cells. Stem Cell Rev Rep (2012) 8 (2):375-92. doi: 10.1007/s12015-011-9312-0

55. Rasmusson I, Uhlin M, Le Blanc K, Levitsky V. Mesenchymal Stem Cells Fail to Trigger Effector Functions of Cytotoxic T Lymphocytes. J Leukoc Biol (2007) 82(4):887-93. doi: 10.1189/jlb.0307140

56. Rasmusson I, Ringdén O, Sundberg B, Le Blanc K. Mesenchymal Stem Cells Inhibit the Formation of Cytotoxic T Lymphocytes, But Not Activated Cytotoxic T Lymphocytes or Natural Killer Cells. Transplantation (2003) 76 (8):1208-13. doi: 10.1097/01.TP.0000082540.43730.80

57. Sakaguchi S, Sakaguchi N, Asano M, Itoh M, Toda M. Immunologic SelfTolerance Maintained by Activated T Cells Expressing IL-2 Receptor AlphaChains (CD25). Breakdown of a Single Mechanism of Self-Tolerance Causes Various Autoimmune Diseases. J Immunol (1995) 155(3):1151-64.

58. Curotto de Lafaille MA, Lafaille JJ. Natural and Adaptive Foxp3+ Regulatory T Cells: More of the Same or a Division of Labor? Immunity (2009) 30 (5):626-35. doi: 10.1016/j.immuni.2009.05.002

59. Lohan P, Murphy N, Treacy O, Lynch K, Morcos M, Chen B, et al. ThirdParty Allogeneic Mesenchymal Stromal Cells Prevent Rejection in a PreSensitized High-Risk Model of Corneal Transplantation. Front Immunol (2018) 9:2666. doi: 10.3389/fimmu.2018.02666

60. Roux C, Saviane G, Pini J, Belaïd N, Dhib G, Voha C, et al. Immunosuppressive Mesenchymal Stromal Cells Derived From HumanInduced Pluripotent Stem Cells Induce Human Regulatory T Cells In Vitro and In Vivo. Front Immunol (2018) 8:1991. doi: 10.3389/fimmu.2017.01991

61. Nam Y, Jung SM, Rim YA, Jung H, Lee K, Park N, et al. Intraperitoneal Infusion of Mesenchymal Stem Cell Attenuates Severity of Collagen Antibody Induced Arthritis. PloS One (2018) 13(6):e0198740. doi: 10.1371/journal.pone.0198740

62. Engela AU, Hoogduijn MJ, Boer K, Litjens NHR, Betjes MGH, Weimar W, et al. Human Adipose-Tissue Derived Mesenchymal Stem Cells Induce Functional De-Novo Regulatory T Cells With Methylated FOXP3 Gene DNA. Clin Exp Immunol (2013) 173(2):343-54. doi: 10.1111/cei.12120

63. English K, Ryan JM, Tobin L, Murphy MJ, Barry FP, Mahon BP. Cell Contact, Prostaglandin E(2) and Transforming Growth Factor Beta 1 Play Non-Redundant Roles in Human Mesenchymal Stem Cell Induction of CD4 +CD25(High) Forkhead Box P3+ Regulatory T Cells. Clin Exp Immunol (2009) 156(1):149-60. doi: 10.1111/j.1365-2249.2009.03874.x

64. Fallarino F, Grohmann U, You S, McGrath BC, Cavener DR, Vacca C, et al. The Combined Effects of Tryptophan Starvation and Tryptophan Catabolites Down-Regulate $\mathrm{T}$ Cell Receptor Zeta-Chain and Induce a Regulatory Phenotype in Naive T Cells. J Immunol (2006) 176(11):675261. doi: 10.4049/jimmunol.176.11.6752

65. Melief SM, Schrama E, Brugman MH, Tiemessen MM, Hoogduijn MJ, Fibbe WE, et al. Multipotent Stromal Cells Induce Human Regulatory T Cells Through a Novel Pathway Involving Skewing of Monocytes Toward AntiInflammatory Macrophages. Stem Cells (2013) 31(9):1980-91. doi: 10.1002/ stem.1432

66. Chiossone L, Conte R, Spaggiari GM, Serra M, Romei C, Bellora F, et al. Mesenchymal Stromal Cells Induce Peculiar Alternatively Activated Macrophages Capable of Dampening Both Innate and Adaptive Immune Responses. Stem Cells (2016) 34(7):1909-21. doi: 10.1002/stem.2369

67. Zhang B, Yin Y, Lai RC, Tan SS, Choo AB, Lim SK. Mesenchymal Stem Cells Secrete Immunologically Active Exosomes. Stem Cells Dev (2014) 23 (11):1233-44. doi: 10.1089/scd.2013.0479

68. Zhang B, Yeo RWY, Lai RC, Sim EWK, Chin KC, Lim SK. Mesenchymal Stromal Cell Exosome-Enhanced Regulatory T-Cell Production Through an
Antigen-Presenting Cell-Mediated Pathway. Cytotherapy (2018) 20(5):68796. doi: 10.1016/j.jcyt.2018.02.372

69. Corcione A, Benvenuto F, Ferretti E, Giunti D, Cappiello V, Cazzanti F, et al. Human Mesenchymal Stem Cells Modulate B-Cell Functions. Blood (2006) 107(1):367-72. doi: 10.1182/blood-2005-07-2657

70. Franquesa M, Mensah FK, Huizinga R, Strini T, Boon L, Lombardo E, et al. Human Adipose Tissue-Derived Mesenchymal Stem Cells Abrogate Plasmablast Formation and Induce Regulatory B Cells Independently of T Helper Cells. Stem Cells (2015) 33(3):880-91. doi: 10.1002/stem.1881

71. Luk F, Carreras-Planella L, Korevaar SS, de Witte SFH, Borràs FE, Betjes $\mathrm{MGH}$, et al. Inflammatory Conditions Dictate the Effect of Mesenchymal Stem or Stromal Cells on B Cell Function. Front Immunol (2017) 8:1042. doi: 10.3389/fimmu.2017.01042

72. Spaggiari GM, Capobianco A, Abdelrazik H, Becchetti F, Mingari MC, Moretta L. Mesenchymal Stem Cells Inhibit Natural Killer-Cell Proliferation, Cytotoxicity, and Cytokine Production: Role of Indoleamine 2,3Dioxygenase and Prostaglandin E2. Blood (2008) 111(3):1327-33. doi: 10.1182/blood-2007-02-074997

73. Sotiropoulou PA, Perez SA, Gritzapis AD, Baxevanis CN, Papamichail M. Interactions Between Human Mesenchymal Stem Cells and Natural Killer Cells. Stem Cells (2006) 24(1):74-85. doi: 10.1634/stemcells.2004-0359

74. Chatterjee D, Tufa DM, Baehre H, Hass R, Schmidt RE, Jacobs R. Natural Killer Cells Acquire CD73 Expression Upon Exposure to Mesenchymal Stem Cells. Blood (2014) 123(4):594-5. doi: 10.1182/blood-2013-09-524827

75. Boissel L, Tuncer HH, Betancur M, Wolfberg A, Klingemann H. Umbilical Cord Mesenchymal Stem Cells Increase Expansion of Cord Blood Natural Killer Cells. Biol Blood Marrow Transplant (2008) 14(9):1031-38. doi: 10.1016/j.bbmt.2008.06.016

76. Hu CD, Kosaka Y, Marcus P, Rashedi I, Keating A. Differential Immunomodulatory Effects of Human Bone Marrow-Derived Mesenchymal Stromal Cells on Natural Killer Cells. Stem Cells Dev (2019) 28(14):933-43. doi: 10.1089/scd.2019.0059

77. Jiang XX, Zhang Y, Liu B, Zhang SX, Wu Y, Yu XD, et al. Human Mesenchymal Stem Cells Inhibit Differentiation and Function of Monocyte-Derived Dendritic Cells. Blood (2005) 105(10):4120-6. doi: 10.1182/blood-2004-02-0586

78. Nauta AJ, Kruisselbrink AB, Lurvink E, Willemze R, Fibbe WE. Mesenchymal Stem Cells Inhibit Generation and Function of Both CD34+-Derived and Monocyte-Derived Dendritic Cells. J Immunol (2006) 177(4):2080-7. doi: 10.4049/jimmunol.177.4.2080

79. Li YP, Paczesny S, Lauret E, Poirault S, Bordigoni P, Mekhloufi F, et al. Human Mesenchymal Stem Cells License Adult CD34+ Hemopoietic Progenitor Cells to Differentiate Into Regulatory Dendritic Cells Through Activation of the Notch Pathway. J Immunol (2008) 180(3):1598-608. doi: 10.4049/jimmunol.180.3.1598

80. Perdiguero EG, Geissmann F. The Development and Maintenance of Resident Macrophages. Nat Immunol (2016) 17(1):2-8. doi: 10.1038/ni.3341

81. Abumaree MH, Al Jumah MA, Kalionis B, Jawdat D, Al Khaldi A, Abomaray FM, et al. Human Placental Mesenchymal Stem Cells (pMSCs) Play a Role as Immune Suppressive Cells by Shifting Macrophage Differentiation From Inflammatory M1 to Anti-Inflammatory M2 Macrophages. Stem Cell Rev $\operatorname{Rep}$ (2013) 9(5):620-41. doi: 10.1007/s12015-013-9455-2

82. Cho DI, Kim MR, Jeong HY, Jeong HC, Jeong $\mathrm{MH}$, Yoon $\mathrm{SH}$, et al Mesenchymal Stem Cells Reciprocally Regulate the M1/M2 Balance in Mouse Bone Marrow-Derived Macrophages. Exp Mol Med (2014) 46(1): e70. doi: 10.1038/emm.2013.135

83. Kloc M, Uosef A, Leśniak M, Kubiak JZ, Ghobrial RM. Reciprocal Interactions Between Mesenchymal Stem Cells and Macrophages. Int J Dev Biol (2020) 64(10-11-12):465-9. doi: 10.1387/ijdb.200242jc

84. Li Y, Zhang D, Xu L, Dong L, Zheng J, Lin Y, et al. Cell-Cell Contact With Proinflammatory Macrophages Enhances the Immunotherapeutic Effect of Mesenchymal Stem Cells in Two Abortion Models. Cell Mol Immunol (2019) 16(12):908-20. doi: 10.1038/s41423-019-0204-6

85. Calderon B, Carrero JA, Ferris ST, Sojka DK, Moore L, Epelman S, et al. The Pancreas Anatomy Conditions the Origin and Properties of Resident Macrophages. J Exp Med (2015) 212(10):1497-512. doi: 10.1084/jem.20150496

86. Dalmas E, Lehmann FM, Dror E, Wueest S, Thienel C, Borsigova M, et al. Interleukin-33-Activated Islet-Resident Innate Lymphoid Cells Promote 
Insulin Secretion Through Myeloid Cell Retinoic Acid Production. Immunity (2017) 47(5):928-42.e7. doi: 10.1016/j.immuni.2017.10.015

87. Weitz JR, Jacques-Silva C, Qadir MMF, Umland O, Pereira E, Qureshi F, et al. Secretory Functions of Macrophages in the Human Pancreatic Islet Are Regulated by Endogenous Purinergic Signaling. Diabetes (2020) 69(6):120618. doi: $10.2337 / \mathrm{db} 19-0687$

88. Raffaghello L, Bianchi G, Bertolotto M, Montecucco F, Busca A, Dallegri F, et al. Human Mesenchymal Stem Cells Inhibit Neutrophil Apoptosis: A Model for Neutrophil Preservation in the Bone Marrow Niche. Stem Cells (2008) 26(1):151-62. doi: 10.1634/stemcells.2007-0416

89. Cassatella MA, Mosna F, Micheletti A, Lisi V, Tamassia N, Cont C, et al. Toll-Like Rceptor-3-Activated Human Mesenchymal Stromal Cells Significantly Prolong the Survival and Function of Neutrophils. Stem Cells (2011) 29(6):1001-11. doi: 10.1002/stem.651

90. Maqbool M, Vidyadaran S, George E, Ramasamy R. Human Mesenchymal Stem Cells Protect Neutrophils From Serum-Deprived Cell Death. Cell Biol Int (2011) 35(12):1247-51. doi: 10.1042/CBI20110070

91. Khalil N. TGF-Beta: From Latent to Active. Microbes Infect (1999) 1 (15):1255-63. doi: 10.1016/s1286-4579(99)00259-2

92. Tomic S, Djokic J, Vasilijic S, Vucevic D, Todorovic V, Supic G, et al. Immunomodulatory Properties of Mesenchymal Stem Cells Derived From Dental Pulp and Dental Follicle are Susceptible to Activation by Toll-Like Receptor Agonists. Stem Cells Dev (2011) 20(4):695-708. doi: 10.1089/ scd.2010.0145

93. Nasef A, Chapel A, Mazurier C, Bouchet S, Lopez M, Mathieu N, et al. Identification of IL-10 and TGF-beta Transcripts Involved in the Inhibition of T-Lymphocyte Proliferation During Cell Contact With Human Mesenchymal Stem Cells. Gene Expr (2007) 13(4-5):217-26. doi: 10.3727/ 000000006780666957

94. Kong QF, Sun B, Bai SS, Zhai DX, Wang GY, Liu YM, et al. Administration of Bone Marrow Stromal Cells Ameliorates Experimental Autoimmune Myasthenia Gravis by Altering the Balance of Th1/Th2/Th17/Treg Cell Subsets Through the Secretion of TGF-Beta. J Neuroimmunol (2009) 207(12):83-91. doi: 10.1016/j.jneuroim.2008.12.005

95. Wang D, Huang S, Yuan X, Liang J, Xu R, Yao G, et al. The Regulation of the Treg/Th17 Balance by Mesenchymal Stem Cells in Human Systemic Lupus Erythematosus. Cell Mol Immunol (2017) 14(5):423-31. doi: 10.1038/ cmi.2015.89

96. Song X, Xie S, Lu K, Wang C. Mesenchymal Stem Cells Alleviate Experimental Asthma by Inducing Polarization of Alveolar Macrophages. Inflammation (2015) 38(2):485-92. doi: 10.1007/s10753-014-9954-6

97. Meisel R, Zibert A, Laryea M, Göbel U, Däubener W, Dilloo D. Human Bone Marrow Stromal Cells Inhibit Allogeneic T-Cell Responses by Indoleamine 2,3-Dioxygenase-Mediated Tryptophan Degradation. Blood (2004) 103 (12):4619-21. doi: 10.1182/blood-2003-11-3909

98. Mounayar M, Kefaloyianni E, Smith B, Solhjou Z, Maarouf OH, Azzi J, et al. Pi3k $\alpha$ and STAT1 Interplay Regulates Human Mesenchymal Stem Cell Immune Polarization. Stem Cells (2015) 33(6):1892-901. doi: 10.1002/ stem.1986

99. Li W, Ren G, Huang Y, Su J, Han Y, Li J, et al. Mesenchymal Stem Cells: A Double-Edged Sword in Regulating Immune Responses. Cell Death Differ (2012) 19(9):1505-13. doi: 10.1038/cdd.2012.26

100. Wang Y, Chen X, Cao W, Shi Y. Plasticity of Mesenchymal Stem Cells in Immunomodulation: Pathological and Therapeutic Implications. Nat Immunol (2014) 15(11):1009-16. doi: 10.1038/ni.3002

101. DelaRosa O, Lombardo E, Beraza A, Mancheño-Corvo P, Ramirez C, Menta $\mathrm{R}$, et al. Requirement of IFN-gamma-Mediated Indoleamine 2,3Dioxygenase Expression in the Modulation of Lymphocyte Proliferation by Human Adipose-Derived Stem Cells. Tissue Eng Part A (2009) 15(10):2795806. doi: 10.1089/ten.TEA.2008.0630

102. Munn DH, Zhou M, Attwood JT, Bondarev I, Conway SJ, Marshall B, et al. Prevention of Allogeneic Fetal Rejection by Tryptophan Catabolism. Science (1998) 281(5380):1191-3. doi: 10.1126/science.281.5380.1191

103. Frumento G, Rotondo R, Tonetti M, Damonte G, Benatti U, Ferrara GB. Tryptophan-Derived Catabolites Are Responsible for Inhibition of $\mathrm{T}$ and Natural Killer Cell Proliferation Induced by Indoleamine 2,3-Dioxygenase. J Exp Med (2002) 196(4):459-68. doi: 10.1084/jem.20020121
104. Ge W, Jiang J, Arp J, Liu W, Garcia B, Wang H. Regulatory T-Cell Generation and Kidney Allograft Tolerance Induced by Mesenchymal Stem Cells Associated With Indoleamine 2,3-Dioxygenase Expression. Transplantation (2010) 90 (12):1312-20. doi: 10.1097/TP.0b013e3181fed001

105. Sato K, Ozaki K, Oh I, Meguro A, Hatanaka K, Nagai T, et al. Nitric Oxide Plays a Critical Role in Suppression of T-Cell Proliferation by Mesenchymal Stem Cells. Blood (2007) 109(1):228-34. doi: 10.1182/ blood-2006-02-002246

106. Ren G, Su J, Zhang L, Zhao X, Ling W, L'Huillie A, et al. Species Variation in the Mechanisms of Mesenchymal Stem Cell-Mediated Immunosuppression. Stem Cells (2009) 27(8):1954-62. doi: 10.1002/stem.118

107. Baratelli F, Lin Y, Zhu L, Yang SC, Heuzé-Vourc'h N, Zeng G, et al. Prostaglandin E2 Induces FOXP3 Gene Expression and T Regulatory Cell Function in Human CD4+ T Cells. J Immunol (2005) 175(3):1483-90. doi: 10.4049/jimmunol.175.3.1483

108. Spaggiari GM, Abdelrazik H, Becchetti F, Moretta L. Mscs Inhibit MonocyteDerived DC Maturation and Function by Selectively Interfering With the Generation of Immature DCs: Central Role of MSC-Derived Prostaglandin E2. Blood (2009) 113(26):6576-83. doi: 10.1182/blood-2009-02-203943

109. Spaggiari GM, Moretta L. Cellular and Molecular Interactions of Mesenchymal Stem Cells in Innate Immunity. Immunol Cell Biol (2013) 91(1):27-31. doi: 10.1038/icb.2012.62

110. Saraiva M, O'Garra A. The Regulation of IL-10 Production by Immune Cells. Nat Rev Immunol (2010) 10(3):170-81. doi: 10.1038/nri2711

111. Chaudhry A, Samstein RM, Treuting P, Liang Y, Pils MC, Heinrich JM, et al. Interleukin-10 Signaling in Regulatory T Cells is Required for Suppression of Th17 Cell-Mediated Inflammation. Immunity (2011) 34(4):566-78. doi: 10.1016/j.immuni.2011.03.018

112. Augello A, Tasso R, Negrini SM, Amateis A, Indiveri F, Cancedda R, et al. Bone Marrow Mesenchymal Progenitor Cells Inhibit Lymphocyte Proliferation by Activation of the Programmed Death 1 Pathway. Eur J Immunol (2005) 35(5):1482-90. doi: 10.1002/eji.200425405

113. Sharpe AH, Pauken KE. The Diverse Functions of the PD1 Inhibitory Pathway. Nat Rev Immunol (2018) 18(3):153-67. doi: 10.1038/nri.2017.108

114. Pennesi G. PD1-Mediated Mesenchymal Stem Cells Immunemodulation: The Two Sides of the Coin. Int Clin Pathol J (2018) 6(4):164-5. doi: 10.15406/icpil.2018.06.00179

115. Davies LC, Heldring N, Kadri N, Le Blanc K. Mesenchymal Stromal Cell Secretion of Programmed Death-1 Ligands Regulates T Cell Mediated Immunosuppression. Stem Cells (20170) 35(3):766-76. doi: 10.1002/ stem. 2509

116. Fiorina P, Jurewicz M, Augello A, Vergani A, Dada S, La Rosa S, et al. Immunomodulatory Function of Bone Marrow-Derived Mesenchymal Stem Cells in Experimental Autoimmune Type 1 Diabetes. J Immunol (2009) 183 (2):993-1004. doi: 10.4049/jimmunol.0900803

117. Jurewicz M, Yang S, Augello A, Godwin JG, Moore RF, Azzi J, et al. Congenic Mesenchymal Stem Cell Therapy Reverses Hyperglycemia in Experimental Type 1 Diabetes. Diabetes (2010) 59(12):3139-47. doi: 10.2337/db10-0542

118. Gu YZ, Xue Q, Chen YJ, Yu GH, Qing MD, Shen Y, et al. Different Roles of PD-L1 and FasL in Immunomodulation Mediated by Human PlacentaDerived Mesenchymal Stem Cells. Hum Immunol (2013) 74(3):267-76. doi: 10.1016/j.humimm.2012.12.011

119. Ren G, Zhang L, Zhao X, Xu G, Zhang Y, Roberts AI, et al. Mesenchymal Stem Cell-Mediated Immunosuppression Occurs Via Concerted Action of Chemokines and Nitric Oxide. Cell Stem Cell (2008) 2(2):141-50. doi: 10.1016/j.stem.2007.11.014

120. Majumdar MK, Keane-Moore M, Buyaner D, Hardy WB, Moorman MA, McIntosh KR, et al. Characterization and Functionality of Cell Surface Molecules on Human Mesenchymal Stem Cells. J BioMed Sci (2003) 10 (2):228-41. doi: 10.1007/BF02256058

121. Ren G, Zhao X, Zhang L, Zhang J, L'Huillier A, Ling W, et al. Inflammatory Cytokine-Induced Intercellular Adhesion Molecule-1 and Vascular Cell Adhesion Molecule-1 in Mesenchymal Stem Cells are Critical for Immunosuppression. J Immunol (2010) 184(5):2321-8. doi: 10.4049/ jimmunol.0902023

122. Li N, Hua J. Interactions Between Mesenchymal Stem Cells and the Immune System. Cell Mol Life Sci (2017) 74(13):2345-60. doi: 10.1007/s00018-017-2473-5 
123. Matula Z, Németh A, Lőrincz P, Szepesi Á, Brózik A, Buzás EI, et al. The Role of Extracellular Vesicle and Tunneling Nanotube-Mediated Intercellular Cross-Talk Between Mesenchymal Stem Cells and Human Peripheral T Cells. Stem Cells Dev (2016) 25(23):1818-32. doi: 10.1089/scd.2016.0086

124. Ribeiro A, Laranjeira P, Mendes S, Velada I, Leite C, Andrade P, et al. Mesenchymal Stem Cells From Umbilical Cord Matrix, Adipose Tissue and Bone Marrow Exhibit Different Capability to Suppress Peripheral Blood B, Natural Killer and T Cells. Stem Cell Res Ther (2013) 4(5):125. doi: 10.1186/ scrt336

125. Ivanova-Todorova E, Bochev I, Mourdjeva M, Dimitrov R, Bukarev D, Kyurkchiev S, et al. Adipose Tissue-Derived Mesenchymal Stem Cells Are More Potent Suppressors of Dendritic Cells Differentiation Compared to Bone Marrow-Derived Mesenchymal Stem Cells. Immunol Lett (2009) 126 (1-2):37-42. doi: 10.1016/j.imlet.2009.07.010

126. Melief SM, Zwaginga JJ, Fibbe WE, Roelofs H. Adipose Tissue-Derived Multipotent Stromal Cells Have a Higher Immunomodulatory Capacity Than Their Bone Marrow-Derived Counterparts. Stem Cells Transl Med (2013) 2(6):455-63. doi: 10.5966/sctm.2012-0184

127. Valencia J, Blanco B, Yáñez R, Vázquez M, Herrero Sánchez C, FernándezGarcía M, et al. Comparative Analysis of the Immunomodulatory Capacities of Human Bone Marrow- and Adipose Tissue-Derived Mesenchymal Stromal Cells From the Same Donor. Cytotherapy (2016) 18(10):1297-311. doi: 10.1016/j.jcyt.2016.07.006

128. Stolzing A, Jones E, McGonagle D, Scutt A. Age-Related Changes in Human Bone Marrow-Derived Mesenchymal Stem Cells: Consequences for Cell Therapies. Mech Ageing Dev (2008) 129(3):163-73. doi: 10.1016/j.mad.2007.12.002

129. Wagner W, Bork S, Horn P, Krunic D, Walenda T, Diehlmann A, et al. Aging and Replicative Senescence Have Related Effects on Human Stem and Progenitor Cells. PloS One (2009) 4(6):e5846. doi: 10.1371/journal.pone.0005846

130. Serena C, Keiran N, Ceperuelo-Mallafre V, Ejarque M, Fradera R, Roche K, et al. Obesity and Type 2 Diabetes Alters the Immune Properties of Human Adipose Derived Stem Cells. Stem Cells (2016) 34(10):2559-73. doi: 10.1002/ stem.2429

131. Kornicka K, Houston J, Marycz K. Dysfunction of Mesenchymal Stem Cells Isolated From Metabolic Syndrome and Type 2 Diabetic Patients as Result of Oxidative Stress and Autophagy May Limit Their Potential Therapeutic Use. Stem Cell Rev Rep (2018) 14(3):337-45. doi: 10.1007/s12015-018-9809-х

132. Gabr MM, Zakaria MM, Refaie AF, Khater SM, Ashamallah SA, Ismail AM, et al. Differentiation of Human Bone Marrow-Derived Mesenchymal Stem Cells Into Insulin-Producing Cells: Evidence for Further Maturation In Vivo. BioMed Res Int (2015) 2015:575837. doi: 10.1155/2015/575837

133. Yoo HS, Yi T, Cho YK, Kim WC, Song SU, Jeon MS. Mesenchymal Stem Cell Lines Isolated by Different Isolation Methods Show Variations in the Regulation of Graft-Versus-Host Disease. Immune Netw (2013) 13(4):13340. doi: 10.4110/in.2013.13.4.133

134. Roemeling-van Rhijn M, Mensah FK, Korevaar SS, Leijs MJ, Van Osch GJVM, IJzermans JNM, et al. Effects of Hypoxia on the Immunomodulatory Properties of Adipose Tissue-Derived Mesenchymal Stem Cells. Front Immunol (2013) 4:203. doi: 10.3389/fimmu.2013.00203

135. Zimmermann JA, McDevitt TC. Pre-Conditioning Mesenchymal Stromal Cell Spheroids for Immunomodulatory Paracrine Factor Secretion. Cytotherapy (2014) 16(3):331-45. doi: 10.1016/j.jcyt.2013.09.004

136. Sundin M, Ringdén O, Sundberg B, Nava S, Götherström C, Le Blanc K. No Alloantibodies Against Mesenchymal Stromal Cells, But Presence of AntiFetal Calf Serum Antibodies, After Transplantation in Allogeneic Hematopoietic Stem Cell Recipients. Haematologica (2007) 92(9):1208-15. doi: 10.3324/haematol.11446

137. Abdelrazik H, Spaggiari GM, Chiossone L, Moretta L. Mesenchymal Stem Cells Expanded in Human Platelet Lysate Display a Decreased Inhibitory Capacity on T- and NK-Cell Proliferation and Function. Eur J Immunol (2011) 41(11):3281-90. doi: 10.1002/eji.201141542

138. Liu H, Lu K, MacAry PA, Wong KL, Heng A, Cao T, et al. Soluble Molecules are Key in Maintaining the Immunomodulatory Activity of Murine Mesenchymal Stromal Cells. J Cell Sci (2012) 125(Pt1):200-8. doi: 10.1242/jcs.093070

139. Holubova M, Lysak D, Vlas T, Vannucci L, Jindra P. Expanded Cryopreserved Mesenchymal Stromal Cells as an Optimal Source for Graft-Versus-Host Disease Treatment. Biologicals (2014) 42(3):139-44. doi: 10.1016/j.biologicals.2014.01.003
140. Gu LH, Zhang TT, Li Y, Yan HJ, Qi H, Li FR. Immunogenicity of Allogeneic Mesenchymal Stem Cells Transplanted Via Different Routes in Diabetic Rats. Cell Mol Immunol (2015) 12(4):444-55. doi: 10.1038/cmi.2014.70

141. de Witte SF, Franquesa M, Baan CC, Hoogduijn MJ. Toward Development of Imesenchymal Stem Cells for Immunomodulatory Therapy. Front Immunol (2016) 6:648. doi: 10.3389/fimmu.2015.00648

142. Lee BC, Kang KS. Functional Enhancement Strategies for Immunomodulation of Mesenchymal Stem Cells and Their Therapeutic Application. Stem Cell Res Ther (2020) 11(1):397. doi: 10.1186/s13287-020-01920-3

143. Krampera M, Cosmi L, Angeli R, Pasini A, Liotta F, Andreini A, et al. Role for Interferon-Gamma in the Immunomodulatory Activity of Human Bone Marrow Mesenchymal Stem Cells. Stem Cells (2006) 24(2):386-98. doi: 10.1634/stemcells.2005-0008

144. Chinnadurai R, Copland IB, Patel SR, Galipeau J. IDO-Independent Suppression of T Cell Effector Function by IFN- $\gamma$-Licensed Human Mesenchymal Stromal Cells. J Immunol (2014) 192(4):1491-501. doi: 10.4049/jimmunol.1301828

145. Polchert D, Sobinsky J, Douglas G, Kidd M, Moadsiri A, Reina E, et al. IFNGamma Activation of Mesenchymal Stem Cells for Treatment and Prevention of Graft Versus Host Disease. Eur J Immunol (2008) 38 (6):1745-55. doi: 10.1002/eji.200738129

146. Duijvestein M, Wildenberg ME, Welling MM, Hennink S, Molendijk I, Van Zuylen VL, et al. Pretreatment With Interferon- $\gamma$ Enhances the Therapeutic Activity of Mesenchymal Stromal Cells in Animal Models of Colitis. Stem Cells (2011) 29(10):1549-58. doi: 10.1002/stem.698

147. Oliveira RL, Chagastelles PC, Sesterheim P, Pranke P. In Vivo Immunogenic Response to Allogeneic Mesenchymal Stem Cells and the Role of Preactivated Mesenchymal Stem Cells Cotransplanted With Allogeneic Islets. Stem Cells Int (2017) 2017:9824698. doi: 10.1155/2017/9824698

148. Yoshihara E, O'Connor C, Gasser E, Wei Z, Oh TG, Tseng TW, et al. Immune-Evasive Human Islet-Like Organoids Ameliorate Diabetes. Nature (2020) 586(7830):606-11. doi: 10.1038/s41586-020-2631-z

149. Sivanathan KN, Gronthos S, Rojas-Canales D, Thierry B, Coates PT. InterferonGamma Modification of Mesenchymal Stem Cells: Implications of Autologous and Allogeneic Mesenchymal Stem Cell Therapy in Allotransplantation. Stem Cell Rev Rep (2014) 10(3):351-75. doi: 10.1007/s12015-014-9495-2

150. Battaglia M, Stabilini A, Roncarolo MG. Rapamycin Selectively Expands CD4+CD25+FoxP3+ Regulatory T Cells. Blood (2005) 105(12):4743-8. doi: 10.1182/blood-2004-10-3932

151. Wang B, Lin Y, Hu Y, Shan W, Liu S, Xu Y, et al. mTOR Inhibition Improves the Immunomodulatory Properties of Human Bone Marrow Mesenchymal Stem Cells by Inducing COX-2 and $\mathrm{PGE}_{2}$. Stem Cell Res Ther (2017) 8 (1):292. doi: 10.1186/s13287-017-0744-6

152. Vaikunthanathan T, Safinia N, Boardman D, Lechler RI, Lombardi G. Regulatory T Cells: Tolerance Induction in Solid Organ Transplantation. Clin Exp Immunol (2017) 189(2):197-210. doi: 10.1111/cei.12978

153. Skuljec J, Chmielewski M, Happle C, Habener A, Busse M, Abken H, et al. Chimeric Antigen Receptor-Redirected Regulatory T Cells Suppress Experimental Allergic Airway Inflammation, A Model of Asthma. Front Immunol (2017) 8:1125. doi: 10.3389/fimmu.2017.01125

154. Garcia-Ocana A, Takane KK, Reddy VT, Lopez-Talavera JC, Vasavada RC, Stewart AF. Adenovirus-Mediated Hepatocyte Growth Factor Expression in Mouse Islets Improves Pancreatic Islet Transplant Performance and Reduces Beta Cell Death. J Biol Chem (2003) 278(1):343-51. doi: 10.1074/jbc.M207848200

155. Qi H, Chen G, Huang Y, Si Z, Li J. Foxp3-Modified Bone Marrow Mesenchymal Stem Cells Promotes Liver Allograft Tolerance Through the Generation of Regulatory T Cells in Rats. J Transl Med (2015) 13:274. doi: 10.1186/s12967-015-0638-2

156. Niu J, Yue W, Song Y, Zhang Y, Qi X, Wang Z, et al. Prevention of Acute Liver Allograft Rejection by IL-10-Engineered Mesenchymal Stem Cells. Clin Exp Immunol (2014) 176(3):473-84. doi: 10.1111/cei.12283

157. Benabdellah K, Sánchez-Hernández S, Aguilar-González A, MaldonadoPérez N, Gutierrez-Guerrero A, Cortijo-Gutierrez M, et al. Genome-Edited Adult Stem Cells: Next-Generation Advanced Therapy Medicinal Products. Stem Cells Transl Med (2020) 9(6):674-85. doi: 10.1002/sctm.19-0338

158. Moghadam F, LeGraw R, Velazquez JJ, Yeo NC, Xu C, Park J, et al. Synthetic Immunomodulation With a CRISPR Super-Repressor In Vivo. Nat Cell Biol (2020) 22(9):1143-54. doi: 10.1038/s41556-020-0563-3 
159. Advani R, Flinn I, Popplewell L, Forero A, Bartlett NL, Ghosh N, et al. Cd47 Blockade by Hu5F9-G4 and Rituximab in Non-Hodgkin's Lymphoma. N Engl J Med (2018) 379(18):1711-21. doi: 10.1056/NEJMoa1807315

160. Willingham SB, Volkmer JP, Gentles AJ, Sahoo D, Dalerba P, Mitra SS, et al. The CD47-signal Regulatory Protein Alpha (SIRPa) Interaction is a Therapeutic Target for Human Solid Tumors. Proc Natl Acad Sci USA (2012) 109(17):6662-7. doi: 10.1073/pnas.1121623109

161. Deuse T, Hu X, Agbor-Enoh S, Jang MK, Alawi M, Saygi C, et al. The Sirp $\alpha$ CD47 Immune Checkpoint in NK Cells. J Exp Med (2021) 218(3):e20200839. doi: $10.1084 /$ jem.20200839

162. Li H, Zhu H, Ge T, Wang Z, Zhang C. Mesenchymal Stem Cell-Based Therapy for Diabetes Mellitus: Enhancement Strategies and Future Perspectives. Stem Cell Rev Rep (2021) 10:1-18. doi: 10.1007/s12015-021-10139-5

163. Al-Daccak R, Charron D. Allogenic Benefit in Stem Cell Therapy: Cardiac Repair and Regeneration. Tissue Antigens (2015) 86(3):155-62. doi: 10.1111/ $\tan .12614$

164. Guan Q, Li Y, Shpiruk T, Bhagwat S, Wall DA. Inducible Indoleamine 2,3Dioxygenase 1 and Programmed Death Ligand 1 Expression as the Potency Marker for Mesenchymal Stromal Cells. Cytotherapy (2018) 20(5):639-49. doi: $10.1016 /$ j.jcyt.2018.02.003
165. Lauden L, Boukouaci W, Borlado LR, López IP, Sepúlveda P, Tamouza R, et al. Allogenicity of Human Cardiac Stem/Progenitor Cells Orchestrated by Programmed Death Ligand 1. Circ Res (2013) 112(3):451-64. doi: 10.1161/ CIRCRESAHA.112.276501

166. Hocine HR, Costa HE, Dam N, Giustiniani J, Palacios I, Loiseau P, et al. Minimizing the Risk of Allo-Sensitization to Optimize the Benefit of Allogeneic Cardiac-Derived Stem/Progenitor Cells. Sci Rep (2017) 7:41125. doi: $10.1038 /$ srep41125

Conflict of Interest: The authors declare that the research was conducted in the absence of any commercial or financial relationships that could be construed as a potential conflict of interest.

Copyright (c) 2021 Refaie, Elbassiouny, Kloc, Sabek, Khater, Ismail, Mohamed and Ghoneim. This is an open-access article distributed under the terms of the Creative Commons Attribution License (CC BY). The use, distribution or reproduction in other forums is permitted, provided the original author(s) and the copyright owner(s) are credited and that the original publication in this journal is cited, in accordance with accepted academic practice. No use, distribution or reproduction is permitted which does not comply with these terms. 